\title{
Vascular Effects of Chronic Arsenic Exposure: A Review
}

\author{
Robert R. Engel, ${ }^{1}$ Claudia Hopenhayn-Rich, ${ }^{1}$ Olivier Receveur, ${ }^{2}$ and Allan H. Smith ${ }^{1}$
}

\section{INTRODUCTION}

The scientific and regulatory focus concerning the effects of chronic inorganic arsenic exposure has been on its carcinogenic properties. Likewise, epidemiologic reviews have dealt with cancer but not with vascular diseases $(1,2)$. Many studies concerning the vascular effects of arsenic have been published, but no synthesis of findings has been presented.

Reports of vascular effects of arsenic, which span almost 100 years, vary with respect to the sources and routes of exposure, the specific disease entities described, and the informativeness of the findings. In this review, we present and summarize the available data on the vascular effects of chronic arsenic exposure and assess the evidence for causality. First, we group and discuss the studies according to the source of exposure: drinking water, wine substitutes, air, and medications. Next, we describe the important similarities and discrepancies between the findings from different sources of exposure and different exposed groups. Finally, we propose possible explanations for the epidemiologic findings.

Received for publication March 15, 1993, and in final form July $25,1994$.

Abbreviations: $\mathrm{Cl}$, confidence interval; SMR, standardized mortality ratio.

'School of Public Health, University of California, Berkeley, CA.

${ }^{2}$ Centre for Nutrition and the Environment of Indigenous Peoples, McGill University, Sainte-Anne-de Bellevue, Quebec, Canada.

Reprint requests to Dr. Robert R. Engel, Federal Office of Public Health, Hess-Strasse 27E, 3097 BernLiebefeld, Switzerland.

\section{ARSENIC IN DRINKING WATER \\ Blackfoot disease endemic area, Taiwan}

An area along the southwestern coast of Taiwan is known for the endemic occurrence of a peripheral vascular disease, locally known as $\mathrm{Wu}$ Chiao Ping, which translates into "blackfoot disease" (3), and which reached a prevalence of nine per 1,000 in the endemic area in the early $1960 \mathrm{~s}$ (4). Early investigations of blackfoot disease (5-12) were followed by additional epidemiologic studies concerning cancer $(4,13-20)$ and cardiovascular diseases $(17$, 20 ), as well as further studies of blackfoot disease $(3,4,13,14,20,21)$.

\section{Blackfoot disease}

Blackfoot disease starts most often with numbness or coldness in a limb and intermittent claudication (7). The toes and feet are primarily involved, with occasional occurrence in the fingers (3). Onset and exacerbation are associated with cold weather and injuries $(3,7,21)$. The agonizingly painful condition ultimately progresses to gangrene, and resulted in spontaneous or surgical amputation in 68 percent of 1,300 blackfoot disease patients in one study (21). Among these patients, age at onset of symptoms ranged from 2 years to 87 years, with 28 percent of patients being under the age of 40 years (21). An earlier study of 327 patients indicated that gangrene developed within a few months to 2 years after disease onset (7). The duration between the first signs of gangrene and spontaneous amputation was between less than 1 month and 2 years (21). The male:female ratio was $3: 2$ 
(21), and female patients tended to be younger than male patients $(3,21)$.

Based on the series of 327 patients, pulsation of affected arteries in the feet was still present in 38.5 percent of arteria dorsalis pedis and in 38.9 percent of arteria tibialis posterior (7). Arteriography was performed on five cases which all showed marked narrowing of major arteries in legs and arms (7). Histologically, thromboangiitis obliterans and arteriosclerosis obliterans have been observed (22). In an early stage of blackfoot disease, thickening and fibrinoid degeneration of the blood vessel wall and perivascular small round cell infiltration of the affected skin have been described (23). Gangrenous limbs showed proliferation and dilation of the dermal vessels and occlusion of subcutaneous arterioles with thrombosis and proliferation of their vasa vasorum (23).

Based on the memory of older residents, blackfoot disease first occurred in the years following the consumption of water from deep (artesian) wells $(9,24)$ which came into use between 1900 and 1930 (3). Because of their high salinity (5), shallow wells were replaced by these deep wells. It was noted in the 1950 s that the distribution of blackfoot disease and the use of deep well water coincided, and an early study (9) established an association between consumption of artesian well water and occurrence of blackfoot disease on an ecologic level. It was also noted that five blackfoot disease patients residing in nonendemic areas, where no artesian wells were used, had migrated away from the endemic area 2 years prior to the onset of the disease (9). A physicochemical study of artesian well water in the affected area found it to contain high levels of arsenic (8). Thus, arsenic was suspected as the main cause of blackfoot disease.

Case-control studies. The first casecontrol study included 353 prevalent cases of blackfoot disease and 353 controls (3). The findings are summarized in table 1 . Consumption of deep well water during the 15 years preceding the onset of disease was found in all of the cases and in
66 percent of the controls ( $p<0.0001$ ). Among subjects exposed to deep well water, the risk was related to the duration of its consumption.

Another case-control study of 241 blackfoot disease patients and 759 controls confirmed the relation between use of deep well water and development of the disease, and found a clear association using a surrogate measure of cumulative arsenic exposure (20). Long-term arsenic poisoning was identified by keratosis or cancer of the skin, two well known effects of chronic arsenic exposure. Logistic regression yielded increased odds ratios for years of use of artesian well water and signs of arsenic poisoning (table 1).

Socioeconomic variables, smoking, nutrition, and family history of blackfoot disease were also investigated in the two casecontrol studies (table 1). Socioeconomic status and education were associated with disease in the first study (3), but no association was found with education in the second investigation (20). Smoking is not a necessary cause of the disease, because almost no female blackfoot disease patients and only about half of the male patients were smokers (3), nor did smoking differ between cases and controls in either of the two studies. The negative results may indicate that blackfoot disease is primarily a small vessel peripheral artery disease which does not share the traditional risk factors of cardiovascular diseases (25). The marginal nutritional status of the population did not differ between cases and controls in one study (3). However, nutrition was found to be important in the study by Chen et al. (20), where high consumption of dried sweet potatoes and low consumption of eggs, meat, and vegetables were associated .with increased risk of blackfoot disease. The negative finding in the first case may have been due to a lack of variation in the source population rather than a lack of importance of nutritional status. Although a family history of blackfoot disease was associated with higher risk, only 14 of 241 cases were classified as having a family history based on numbers of affected and 
TABLE 1. Case-control studies of blackfoot disease in Taiwan

\begin{tabular}{|c|c|c|}
\hline & \multicolumn{2}{|c|}{ Case-control study } \\
\hline & $\mathrm{Ch}^{\prime} \mathrm{i}$ and Blackwell (3) & Chen et al. (20) \\
\hline Subjects & $\begin{array}{l}353 \text { prevalent blackfoot disease patients; } \\
353 \text { sex, age, and district matched } \\
\text { controls }\end{array}$ & $\begin{array}{l}241 \text { prevalent blackfoot disease } \\
\text { patients; } 759 \text { sex, age, and } \\
\text { township matched controls }\end{array}$ \\
\hline $\begin{array}{l}\text { Variables } \\
\text { Deep well water }\end{array}$ & $\begin{array}{l}\text { Consumption during } 15 \text { years prior to } \\
\text { disease onset: all } 353 \text { cases, } 233 \\
(66 \%) \text { controls }(p<0.0001)^{*} \\
\text { Among subjects consuming deep well } \\
\text { water, period of consumption of } \\
\text { more vs. less than } 10 \text { years: OR }= \\
2.58(95 \% \mathrm{C} \mid 11.47-4.61)^{*}\end{array}$ & $\begin{array}{l}\text { Odds ratios } \dagger \text { for years of consumption: } \\
0 \text { years, } \text { OR } \neq=1.00 \\
1-29 \text { years, } O R=3.04 \\
\geq 30 \text { years, } \text { OR }=3.47 \\
\text { Trend-test, } p<0.001\end{array}$ \\
\hline Arsenic & Not investigated & $\begin{array}{l}\text { Cutaneous signs of arsenic poisoning } \\
\text { (keratoses or cancer): yes vs. no, } \\
\text { ORt }=2.77(p<0.01)\end{array}$ \\
\hline Cigarette smoking & $\begin{array}{l}\text { Males, overall, OR }=0.88(95 \% \mathrm{Cl} \\
\quad 0.57-1.35)^{*} \\
\text { Disease onset }<30 \text { years, OR }=2.15 \\
\quad(95 \% \mathrm{Cl} 0.69-6.90)^{*} \\
\text { Disease onset }>30 \text { years, OR }=0.73 \\
\quad(95 \% \mathrm{Cl} 0.46-1.18)^{*}\end{array}$ & $\begin{array}{l}\text { Yes vs. no, } \mathrm{OR}=0.87(95 \% \mathrm{Cl} \\
0.62-1.2)^{*}\end{array}$ \\
\hline Nutrition & $\begin{array}{l}\text { No data but text mentions absence of } \\
\text { association }\end{array}$ & 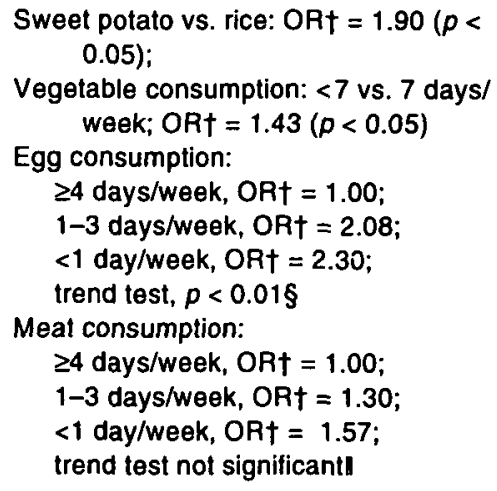 \\
\hline Family history & Not investigated & Yes vs. nol, OR $\dagger=3.29(p<0.01)$ \\
\hline $\begin{array}{l}\text { Socioeconomic } \\
\text { status }\end{array}$ & $\begin{array}{l}\text { Among subjects with deep well water as } \\
\text { principle source, levels of socio- } \\
\text { economic status: } \\
\text { Above average, OR }=1 \\
\text { Average, OR }=3.30 \\
\text { Below average, OR }=4.55 \\
\text { Trend test, } p<0.0001^{*} \\
\text { No vs. some education: OR }=1.48 \\
(95 \% \mathrm{Cl} 1.02-2.15)^{*}\end{array}$ & $\begin{array}{l}\text { Formal education, yes vs. no: } \\
\qquad \text { OR } \dagger=1.03 \text { (not significant)" }\end{array}$ \\
\hline
\end{tabular}

* Calculated from data.

$\dagger$ Adjusted odds ratios (logistic regression)

$\ddagger \mathrm{OR}$, odds ratio: $\mathrm{Cl}$, confidence interval

$\$$ In Chen et al. (20), the $\rho$ value $0^{\circ}<0.10^{\circ}$ in table 4 is probably an error, the univariate trend test (table 3 ) gives $p<0.01$

I Alpha level not indicated.

7) Based on numbers of affected and unaffected first-degree relatives, criteria for the variable "family history" not indicated. 
unaffected first-degree relatives (20). Furthermore, the study was not designed to disentangle environmental and genetic influences. The adjustment for arsenic consumption was based on the presence or absence of chronic arsenicalism, thus leaving room for residual confounding in assessing family history.

The co-occurrence of blackfoot disease with bladder, kidney, and skin cancer. It has been established that ingestion of inorganic arsenic causes skin cancer (26). There is also evidence that ingestion of inorganic arsenic can cause internal cancers. Bates et al. (2) reviewed the evidence for causality in detail, and a risk assessment using data from Taiwan provides quantitative risk estimates under the assumption of causality (27). The steepest dose-response gradients were observed for bladder and kidney cancers.

An excess co-occurrence of blackfoot disease with these cancers (or with cutaneous signs of chronic arsenicalism) would be expected if arsenic were a cause of both blackfoot disease and these cancers. In a cross-sectional survey of 40,421 persons in the blackfoot disease endemic area, the co-occurrence of blackfoot disease with skin cancer and with keratosis (a sign of arsenicalism) was far beyond what was expected under stochastic independence (13) (table 2).

An ecologic investigation examined cancer mortality in the blackfoot disease endemic area and the association between cancer mortality and prevalence rates of blackfoot disease (table 2) (14). High standardized mortality ratios for skin, bladder, and kidney cancer were observed in both sexes in the blackfoot disease endemic area compared with the general Taiwanese population. Standardized mortality ratios ranged from 5.34 for skin cancer in males to 20.09 for bladder cancer in females. After villages were grouped according to three categories of blackfoot disease prevalence rates, "dose-response" patterns emerged for the standardized mortality ratios of the three cancers, although no measure of precision or formal statistical analyses were presented for the relations.

A retrospective cohort study of 871 blackfoot disease patients investigated their mortality experience between 1968 and 1983 (20) (table 2). Compared with mortality rates in the blackfoot disease endemic area, blackfoot disease patients showed age- and sex-adjusted standardized mortality ratios of $1.60,2.55$, and 4.51 for kidney, bladder, and skin cancer, respectively.

Arsenic in deep well water and prevalence of blackfoot disease. A cross-sectional survey of 40,421 persons related the prevalence rates of blackfoot disease to the quantitative arsenic content in well water at the village level (4). We statistically related arsenic levels to blackfoot disease prevalence rates based on data from the paper of Tseng (ref. 4, figure 6), which provides age- and sex-specific prevalence rates of blackfoot disease for four groups of villages according to the arsenic level in well water (low, medium, high, and unknown). Average arsenic concentrations for the first three groups have been estimated as 170 , 470 , and $800 \mu \mathrm{g} /$ liter (28). Estimates of the population at risk (28) specific to sex, age group, and arsenic level are shown in table 3 . The age- and sex-specific prevalence rates and population estimates were used to calculate the number of cases in each stratum which, together with the population number, allowed the use of the Mantel extension for the overall trend (29). The trend tests were significant for both females and males $(p<0.001)$ across the three arsenic categories using three age strata (table 3 ).

Assessment of the roles of deep well water and arsenic in blackfoot disease. The epidemiologic data indicate that consumption of deep well water is associated with blackfoot disease in Taiwan. The "effect" of this artesian water was so large that the association had been perceived by the population itself. The two case-control studies described above support a possible causal role of deep well water in blackfoot disease by both large measures of effect and doseresponse relations. Consumption of the drinking water may even be a necessary cause, since in one study all cases were 
TABLE 2. Studies of the co-occurrence of blackfoot disease with bladder, kidney, and skin cancer

\begin{tabular}{|c|c|c|c|}
\hline $\begin{array}{c}\text { Study } \\
\text { (reference no.) }\end{array}$ & Study design & Study subjects & Results \\
\hline Tseng et al. (13) & $\begin{array}{c}\text { Cross-sectional, } \\
1963-1965\end{array}$ & $\begin{array}{l}\text { Survey of } 40,421 \text { persons } \\
\text { in blackfoot disease } \\
\text { endemic area }\end{array}$ & $\begin{array}{l}\text { Co-occurrence of blackfoot disease and } \\
\text { skin cancer: observed, } 61 ; \\
\text { expected, } 4 \text {; observed/expected, } \\
16.77 \\
\text { Co-occurrence of blackfoot disease and } \\
\text { keratosis: observed, } 135 ; \\
\text { expected, }{ }^{*} 26 ; \text { observed/expected, } \\
5.3 \\
\text { Co-occurrence of blackfoot disease, } \\
\text { skin cancer, and keratosis: } \\
\text { observed, } 46 ; \text { expected,*0.3; } \\
\text { observed/expected, } 162.85\end{array}$ \\
\hline Chen et al. (14) & Ecologic & Mortality period 1968-1982 & 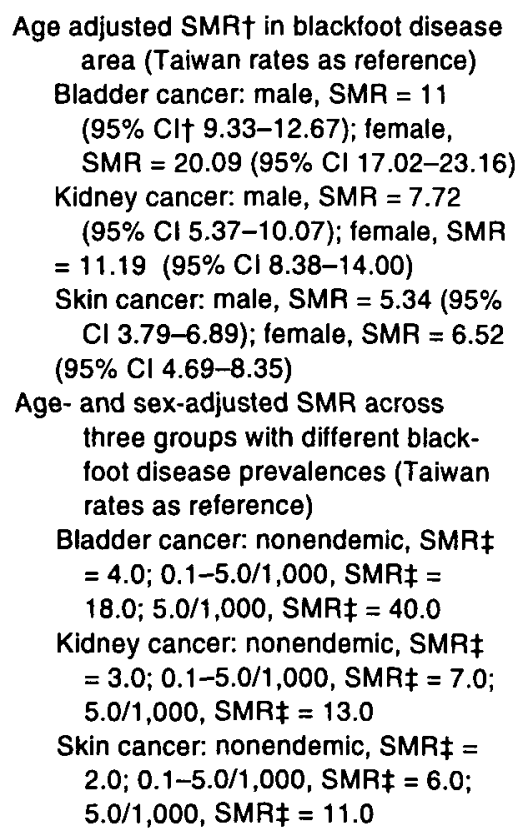 \\
\hline Chen et al. (20) & Cohort & $\begin{array}{l}\text { Mortality experience of } \\
871 \text { blackfoot disease } \\
\text { patients, 1968-1983 }\end{array}$ & $\begin{array}{l}\text { Age- and sex-adjusted SMR (blackfoot } \\
\text { disease endemic area rates as } \\
\text { reference) } \\
\text { Bladder cancer: SMR = } 2.55(95 \% \\
\text { CI§ 1.43-4.21) } \\
\text { Kidney cancer: SMR = } 1.60(95 \% \\
\text { Cl§ 0.33-4.68) } \\
\text { Skin cancer: SMR }=4.51(95 \% \mathrm{Cl} \\
1.81-9.29)\end{array}$ \\
\hline
\end{tabular}

* Under the assumption of independent occurrence; numbers are rounded.

† SMR, standardized mortality ratio; $\mathrm{Cl}$, confidence interval.

$\ddagger$ Estimated from logarithmic bar graphs, no measure of precision given.

$\$$ Calculated from data.

exposed (3). In the later case-control study, 26 of 241 cases were in the group "none" for years of artesian well water consumption, but it is not clear how many of these cases were exposed for less than a year and how many not at all (20). Recall may also have been problematic, because "duration of drinking water since early childhood" had to be remembered. Furthermore, water may have been used for cooking but not for 


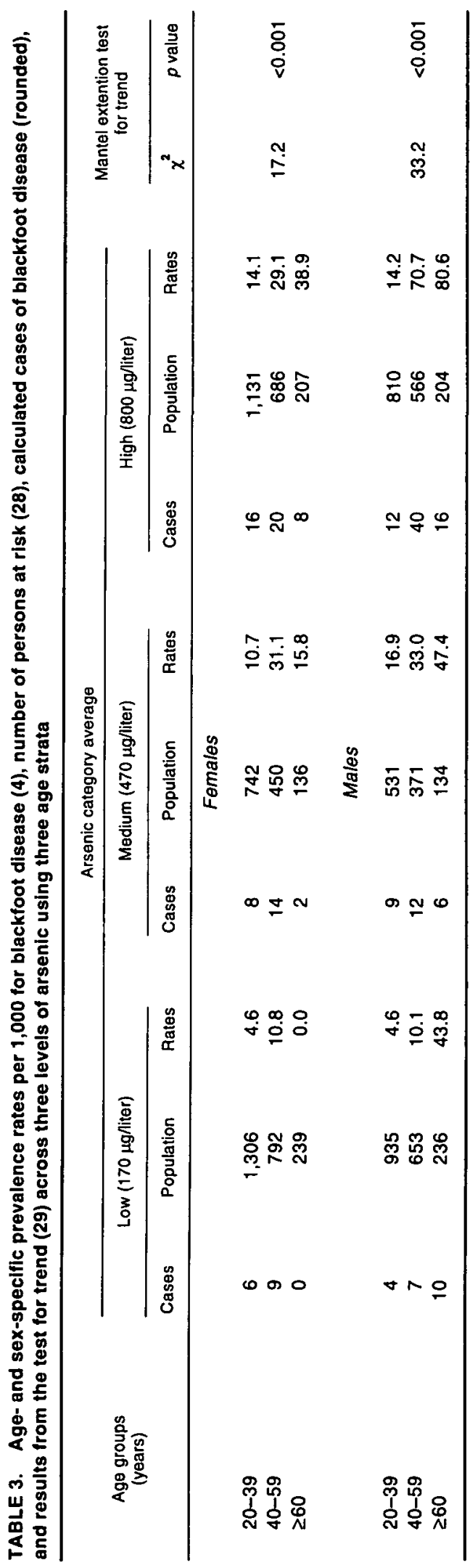

drinking. Finally, the study may have included cases of ischemia due to traditional causes (e.g., smoking, diabetes).

Is the association between arsenic in artesian well water and blackfoot disease a causal one? In one case-control study (20) and in a survey of 40,421 persons (13), blackfoot disease co-occurred with cutaneous signs of arsenicalism to an extent unexplainable by chance; nor can chance account for the higher mortality among blackfoot disease patients from arsenicrelated skin cancer, as well as bladder and kidney cancer. Is it possible that blackfoot disease makes patients more likely to express cutaneous signs after arsenic exposure and more susceptible to the cancers in question? This reasoning cannot be rejected as an explanation for some of the above observations, but it would fail to explain the dose-response relation between blackfoot disease prevalence rates and arsenic content in the deep wells (4). Another possibility is that a component of drinking water other than arsenic causes blackfoot disease. Humic substances have been proposed as such a possibility.

Humic substances. Humic substances in drinking water have been proposed to be a cause of blackfoot disease (30). Initially, it was reported that "ergotamine, D-lysergic acid, and/or ergometrine might be present" in water samples from the blackfoot disease area (31). However, it is not clear whether these findings have been confirmed, and more recent studies do not mention ergotamine-like substances $(30,32-34)$. Rather, it was pointed out that the complex composition of the well water prevents a detailed chemical characterization (35). This is important, since the initial interest in humic substances stemmed from the potent vasoconstrictive effect of ergotamine (36). While in vitro studies reported that the humic substances influence parameters of the blood coagulation system (32-34) and capillary permeability (23), no epidemiologic data have so far been presented (37). Lu (30) merely noted that "the intensity of the fluorescence bore some relation to the incidence of blackfoot disease," citing Lu et 
al. (38), where, in the English abstract, nine correlation coefficients for fluorescent characteristics are reported. However, the derivation and interpretation of these correlation coefficients was not presented, and there is no indication that adjustment was made for arsenic exposure.

An animal experiment which treated 16 male Balb/c mice with intraperitoneal injection of fluorescent compounds dissolved in deionized water over 22-23 days resulted in "crippling, phlegmasia, ulceration, necrosis, and gangrene in extremities" in eight mice (39). Since no control mice were used, no conclusion of causality can be drawn from this study. In a much larger series of 300 mice exposed to humic acids in their drinking water for 24 months, gangrenous changes were not reported (40).

Because of the strong relation of blackfoot disease with arsenic exposure, the association between humic substances and blackfoot disease, and the relation between arsenic and humic substances in water, would have to be very strong for the arsenic association to be the result of confounding.
In conclusion, the almost 20-year-old hypothesis (38) that humic substances play an etiologic role in blackfoot disease has not been substantiated by epidemiologic or animal studies. A causal role for arsenic in the induction of blackfoot disease offers the best explanation for the observations in Taiwan.

\section{Mortality due to vascular diseases}

$\mathrm{Wu}$ et al. (17) conducted an ecologic study involving 42 villages in six townships in the endemic area (table 4). The choice of villages was guided by the availability of arsenic data. Rates of mortality from various cancers and vascular diseases were analyzed with respect to the median arsenic level of water samples within a village. Statistically significant trends were reported for all vascular diseases together, for cardiovascular but not cerebrovascular diseases, and for diseases of the arteries, arterioles, and capillaries (corresponding to International Classification of Diseases, Eighth Revision (40a) codes 440 through

TABLE 4. Relation between arsenic in well water and mortality from vascular diseases in an ecologic study by Wu et al. (17); age adjusted mortality rates (per 100,000*), 1973-1986, and number of deaths among residents 20 years and older, by median arsenic level

\begin{tabular}{|c|c|c|c|c|c|c|c|c|}
\hline \multirow{3}{*}{$\begin{array}{l}\text { Median arsenic level } \\
\text { in well water } \\
\text { (mg/liter) }\end{array}$} & \multicolumn{8}{|c|}{ Causes of death } \\
\hline & \multicolumn{2}{|c|}{$\begin{array}{c}\text { All vascular diseases } \\
(401-448) \dagger\end{array}$} & \multicolumn{2}{|c|}{$\begin{array}{l}\text { Diseases of arteries, } \\
\text { arterioles, and } \\
\text { capillaries } \\
(440-448) \dagger\end{array}$} & \multicolumn{2}{|c|}{$\begin{array}{c}\text { Cardiovascular diseases } \\
(410-414,420-429) \dagger\end{array}$} & \multicolumn{2}{|c|}{$\begin{array}{c}\text { Cerebrovascular } \\
\text { diseases } \\
(430-438) t\end{array}$} \\
\hline & Ratef & $\begin{array}{l}\text { No. of } \\
\text { deaths }\end{array}$ & Ratef & $\begin{array}{l}\text { No. of } \\
\text { deaths }\end{array}$ & Ratef & $\begin{array}{l}\text { No. of } \\
\text { deaths }\end{array}$ & Ratef & $\begin{array}{l}\text { No. of } \\
\text { deaths }\end{array}$ \\
\hline \multicolumn{9}{|c|}{ Males } \\
\hline$<0.3$ & 364.10 & 363 & 22.54 & 21 & 125.87 & 127 & 137.80 & 137 \\
\hline $0.3-0.59$ & 421.47 & 230 & 57.80 & 29 & 153.98 & 85 & 145.36 & 81 \\
\hline$\geq 0.6$ & 572.68 & 136 & 60.40 & 14 & 259.51 & 62 & 175.72 & 44 \\
\hline$\rho$ value & \multicolumn{2}{|c|}{$<0.001$} & \multicolumn{2}{|c|}{$<0.001$} & \multicolumn{2}{|c|}{$<0.001$} & \multicolumn{2}{|c|}{ NSI } \\
\hline \multicolumn{9}{|c|}{ Females } \\
\hline$<0.3$ & 277.50 & 320 & 18.20 & 21 & 91.14 & 105 & 92.42 & 106 \\
\hline $0.3-0.59$ & 370.79 & 226 & 48.00 & 29 & 153.07 & 93 & 98.11 & 60 \\
\hline$\geq 0.6$ & 386.41 & 93 & 35.82 & 8 & 144.74 & 37 & 120.68 & 30 \\
\hline$\rho$ value $\S$ & \multicolumn{2}{|c|}{$<0.001$} & \multicolumn{2}{|c|}{$<0.05$} & \multicolumn{2}{|c|}{$<0.001$} & \multicolumn{2}{|c|}{ NS』 } \\
\hline
\end{tabular}

* Standard: 1976 world population.

+ International Classification of Diseases, Eighth Revision, codes.

$\ddagger$ Age-adjusted mortality rates.

$\S \rho$ value for trend from Mantel extention test (29).

i NS, statistically not significant. 
448 referred to by Wu et al. (17) as peripheral vascular diseases). The authors' conclusion that peripheral vascular diseases showed a dose-response relation with arsenic levels in well water has been criticized on the grounds that no incremental risk was observed between the moderate and high exposure groups (41). Even assuming that the trends are real, questions of interpretation arise. Since the deaths from vascular causes included blackfoot disease patients, these alone could explain the trend. If so, no new knowledge would have been conveyed. Based on the reasoning presented in the Appendix, we conclude that this may be numerically possible. Another scenario would be that "excess mortality ... was observed for residents in the study area" (17), implying increased risks across arsenic categories affecting residents independently of blackfoot disease. The two scenarios are not mutually exclusive.

While there are no reports contrasting vascular mortality rates for the whole blackfoot disease endemic area with the Taiwanese general population rates, the data from Chen et al. (20) can be used to make such comparisons. In this study of blackfoot disease patients, mortality rates in both the blackfoot disease endemic area and in all of Taiwan were used to generate the expected number of deaths from each cause. This allowed estimation of relative risks for the blackfoot disease area compared with Taiwan as a whole (table 5). The resulting relative risks were 3.5 for diseases of the arteries, arterioles, and capillaries,
1.3 for cardiovascular disease, and 1.1 for cerebrovascular diseases. The vascular mortality rates, based on residents of the blackfoot disease endemic area, included deaths of blackfoot disease patients. Under the assumption that blackfoot disease patients accounted for half of the deaths due to diseases of the arteries, arterioles, and capillaries, their subtraction from the denominator still leaves a relative risk of 1.77 for the blackfoot disease area as a whole compared with the entire country of Taiwan.

In conclusion, while there is good epidemiologic evidence supporting a causal association between inorganic arsenic in well water and occurrence of blackfoot disease, the evidence for an effect on vascular disease mortality independent of blackfoot disease is less compelling.

\section{Reichenstein, Silesia}

In 1898, Geyer (42) reported an increased occurrence of gangrene ("Altersbrand") in Reichenstein, Silesia (now part of Poland). The population was exposed to high levels of arsenic in the brooks (a level of $12,000 \mu \mathrm{g} /$ liter has been reported (1)) stemming from gold-containing arsenical ores. Residents suffered from many signs and symptoms of arsenicalism (disease of Reichenstein), and there is an oral report that "half of the patients ... had died of cancer" (1). A search for further information from this area failed $(43,44)$.

TABLE 5. Standardized mortality ratio I (SMR I), based on Taiwan rates, and standardized mortality ratio II (SMR II), based on blackfoot disease area rates, for 871 blackfoot disease patients in the study of Chen et al. (20)

\begin{tabular}{lccc}
\hline \multicolumn{1}{c}{ Disease } & SMR I (95\% Cl*) & SMR II (95\% CI) & SMR I/SMR IIt \\
\hline Diseases of arteries, arterioles, and & & & \\
$\quad$ capillaries $(440-448) \ddagger$ & $12.43(9.28-16.30)$ & $3.51(2.62-4.60)$ & 3.54 \\
Cardiovascular diseases $(410-429) \ddagger$ & $2.09(1.70-2.55)$ & $1.60(1.30-1.95)$ & 1.31 \\
Cerebrovascular diseases $(430-438) \ddagger$ & $1.18(0.86-1.58)$ & $1.07(0.78-1.43)$ & 1.10 \\
\hline
\end{tabular}

* $\mathrm{Cl}$, confidence interval (calculated from data).

† Dividing SMR I by SMR II results in the relative risks for the blackfoot disease area compared with Taiwan (i.e. SMR I/SMR

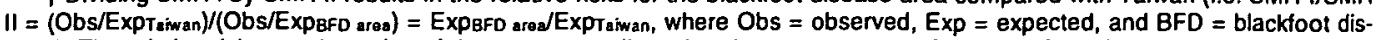
ease). The relative risks are the ratios of the wo rates adjusted to the age structure of the blackfoot disease population (SMR I and SMR II are comparable because they are standardized to the same population).

$\ddagger$ International Classification of Diseases, Eighth Revision, codes. 


\section{Latin America}

Populations in Chile, Mexico, and Argentina have been exposed to levels of arsenic in drinking water comparable to those from the blackfoot disease endemic area in Taiwan. While there are some reports of vascular manifestations, an occurrence of gangrene and amputations comparable to the magnitude found among blackfoot disease patients in Taiwan has not been described.

Chile. The inhabitants of the city of Antofagasta were exposed to high levels of arsenic in public drinking water for at least 12 years up to 1970 (45). In 1958, the need for a larger supply led to the inclusion of water from two rivers, which were found to have elevated arsenic levels of around 600 $\mu \mathrm{g} /$ liter (46). After 1970, a treatment plant reduced the arsenic content to levels around the standard of $50 \mu \mathrm{g} / \mathrm{liter}$.

The first cutaneous signs of arsenic poisoning in children were noted in 1962 (47). After 1968, some patients showed vascular spasm of the fingers, feet, and tongue with histologic changes in accordance with Raynaud's disease (hypertrophic media of the artery). Several patients were reported to have necrosis of the fingers, which in some instances led to amputations (47). Among 100 affected children, 19 had arterial spasms in the fingers and toes. There was one case of gangrene of a finger, and four cases of ischemia of the tongue. Raynaud's syndrome was found in 20 percent of the boys and 17 percent of the girls (48). Zaldivar (47) described five children with cutaneous signs of arsenicalism who died of vascular causes with involvement of the coronary, cerebral, and mesenteric arteries and the carotids. Intimal thickening of the medium- and small-sized arteries in many organs was found in five deceased children investigated by Rosenberg (49), who noted the resemblance of the histopathologic findings to reports from Taiwan. A report of two young, nonsmoking males who suffered myocardial infarction noted that one of them had progressive intermittent claudication and developed gangrene on a foot (50).
Among 166 patients with myocardial infarction who sought care at the Regional Hospital of Antofagasta between 1967 and 1970, 30 (18.1 percent) were diagnosed with chronic arsenic poisoning (47). Of these, 30 percent were under the age of 40 years, compared with 5.9 percent of those without arsenical signs at the same hospital and 1.5 percent of 200 patients from a hospital series in Santiago (51).

In a study of 180 persons from Antofagasta, Borgono et al. (45) compared 144 persons with abnormal skin pigmentation and 36 persons with normal skin. Raynaud's syndrome (38.8 percent vs. 9.3 percent) and acrocyanosis ( 24.3 percent vs. 12.5 percent) were more prevalent among those with skin abnormalities, who were also more likely to have hyperkeratosis (43.7 percent vs. 3.1 percent)

The population of the city of Antofagasta in 1970 was 138,000 , and in the whole province 265,000 people were known to be exposed to high arsenic levels in drinking water (46). The population size and age structure were similar to those of the blackfoot disease endemic area $(13,48)$. Children and young adults had durations and levels of exposure comparable to those in Taiwan, where over a 2.5-year period in the late 1950s, 17 cases of blackfoot disease in children aged birth to 9 years and 46 cases in children aged 10-19 years were diagnosed (5). One would expect a similar number of cases to have occurred in Antofagasta by 1970 , at least in the youngest age group, where lifetime exposure would have occurred. However, it was reported only that "several cases had necrosis of the fingers and required amputations"; actual numbers were not presented (47).

Mexico. Chronic arsenicalism is endemic in some rural parts of the Region Lagunera, located in northern Mexico. A study comparing the clinical findings of residents of El Salvador de Arriba (water arsenic levels of $410-500 \mu \mathrm{g} /$ liter) with those of residents of San Jose del Vinedo (water arsenic levels of $1-5 \mu \mathrm{g} / \mathrm{liter}$ ) found that in the exposed town, 22 percent (of 296 residents) had cutaneous signs of arsenical- 
ism, compared with 2.2 percent (of 318 residents) in the control town $(52,53)$. Many additional symptoms of various organs and systems were investigated (52). However, no mention was made of peripheral vascular alterations, gangrene, or amputations. Given that 33 percent of residents suffered from skin disorders considered precancerous, and that the arsenic content of the water was between the medium and high categories of the wells in Taiwan, one would expect around 10 cases of blackfoot disease (an approximation based on the rates from table 3 ).

In a short paper published later, 4 percent of the exposed population were described as having peripheral vascular alterations in different stages of severity which led to amputations in 0.7 percent of the cases (54). However, it is not clear from the report which population is being characterized, although from a personal communication with the author, it seems to correspond to the same one described above. If so, two of the 296 people sampled would have suffered amputations.

In the Region Lagunera, there are $\mathbf{1 1}$ counties exposed to water with arsenic levels ranging from $100 \mu \mathrm{g} /$ liter to $500 \mu \mathrm{g} /$ liter, with an estimated population of $127,000(55)$. This corresponds to at least the low level in the Taiwanese studies (median: $170 \mu \mathrm{g} /$ liter) (4). Although the signs of arsenical skin disorders were very similar, there is no report of a comparable occurrence of blackfoot disease in the Mexican exposed population of the Region Lagunera.

A series of earlier papers $(56-58)$ presented the results of a detailed study carried out in two villages totaling 474 people in the state of Coahuila. In one of the villages, the only source of drinking water was a well that reached arsenic levels of 3,980 $\mu \mathrm{g} /$ liter (56). The study comprised environmental and biologic exposure measurements, as well as a comprehensive clinical examination of a sample of 294 residents, investigating 41 symptoms and other possible manifestations attributable to arsenic intoxication (57). About 60 percent of the population was considered affected (56). Again, although all of the typical signs of arsenical skin disease were commonly found, in addition to many other systemic symptoms of toxicity, no gangrene or amputations were reported.

Argentina. There are several regions in Argentina known for having high levels of arsenic in drinking water, with many reports documenting the same types of skin alterations found in other exposed populations. In particular, people from areas in the provinces of Cordoba (59-63) and Salta (64) have been affected. However, no systematic survey has been conducted to assess the extent of arsenic-related diseases or arsenic exposure in these areas.

The province of Cordoba had a population of about 1.7 million in the early $1960 \mathrm{~s}$ (65), and arsenic in drinking water was considered prevalent in a third of the area of the province (66). Residents of one survey were exposed to drinking water with levels ranging from $100 \mu \mathrm{g} /$ liter to 1,200 $\mu \mathrm{g} /$ liter (61). A sampling of 60 water sources taken from a vast area of the affected region found arsenic levels ranging from $18 \mu \mathrm{g} /$ liter to $3,810 \mu \mathrm{g} /$ liter, with a median of $410 \mu \mathrm{g} /$ liter (67).

Most of the information on health effects comes from publications by dermatologists, such as Tello and Biagini, who have treated many cases of arsenical skin disorders, visited the endemic areas, and followed their patients for several years. In one series, 339 cases of skin cancer were diagnosed in persons with clear manifestations of chronic arsenic intoxication (62). In Belleville, Cordoba, 511 persons sought treatment in the local hospital for arsenical disease between 1934 and 1944 (68). The population of the town in 1990 was about 30,000 (H. B. Nicolli, Comisión Nacional de Investigationes Especiales, San Miguel-Bu.As., Argentina, personal communication, 1992). If one assumes that it was that high in 1940 (a conservative estimate), almost 2 percent of patients presented to one hospital. Clearly, the extent of the problem was considerable.

However, there is no description of the occurrence of peripheral vascular disease 
such as blackfoot disease in association with arsenic in drinking water. In fact, reports from Argentina state that the pathology observed is different from that seen in the Taiwanese, mainly because of the absence of blackfoot disease (62). In a recent study in the province of Salta, angiographic studies of the lower extremities of $12 \mathrm{pa}$ tients suffering from dermatologic arsenic disease were conducted (69). In all cases, microangiopathies were observed, with obstruction of the terminal arteries. It was noted that 66 percent of the patients were under 50 years of age; half of those were under age 25 years. However, no controls were used. There was one reported case of a leg amputation in a man from the endemic arsenic area of Salta (69), but the possibility of an underlying condition, such as diabetes, was not addressed.

One of the authors of this paper (C. H. R.) communicated personally (in 1993) with Drs. Tello (Cordoba, Argentina) and Biagini (Hospital del Milagro, Salta, Argentina). They both stated that signs of peripheral vascular disease were not apparent in their case series, which included many patients with arsenical skin disorders from high arsenic areas.

Assessment. It is clear from the literature that in Mexico, Chile, and Argentina, sizable populations have been exposed to arsenic from drinking water. The skin disorders of residents living in the affected areas are typical of chronic arsenic toxicity, and are similar to those found in Taiwan.

Regarding peripheral vascular alterations, reports from Chile indicate the occurrence of Raynaud's syndrome and some cases of acrocyanosis and necrosis of fingers. In Mexico, none of the papers in which extensive symptomatology of severely intoxicated individuals was reviewed cited similar pathologies, except for one short article reporting two cases of gangrene with amputation. In Argentina, peripheral vascular disease has not been observed, although one recent study reported microangiopathic changes in the extremities of patients with arsenical disease, as revealed by arteriography.
In summary, although there are some indications of peripheral vascular involvement, they do not compare in magnitude or severity to blackfoot disease in the endemic area of Taiwan.

\section{ARSENIC IN WINE SUBSTITUTES \\ Exposed populations}

German vintners were heavily exposed to inorganic arsenic between 1921 and 1942 through the application of arsenical pesticides. While the spraying of grapes itself only occurred on 1-14 days per year, significant exposure occurred through ingestion of a "house drink" (Haustrunk) prepared from the grape skins left over from the first press (70). This low-alcohol beverage was consumed throughout the year and contained variably high levels of arsenic reaching up to $10 \mathrm{mg} /$ liter. The wine was also found to be contaminated with arsenic: In Palatinate, 63 percent of 336 samples from 1938 contained more than 2 $\mathrm{mg}$ /liter, and of these, 43 percent had levels over $5 \mathrm{mg} /$ liter (70).

The occurrence of peripheral arterial diseases has been reported from the winemaking regions of Palatinate $(70,71)$ and the Moselle area (72-75) and from Austria (76). Signs of chronic arsenic exposure, however, were first reported in the Kaiserstuhl region (South Baden) during the 1920s.

In Palatinate, among 80 cases with cutaneous signs of chronic arsenicalism between 1935 and 1945, 13 had severe peripheral arterial disease leading to amputation of toes, with amputation below the knee in two people and amputation of both legs in two others (70). Amputation of toes, and later of one leg below the knee, in a hairdresser who never applied insecticides but drank a substantial amount of "house drink" was also reported (77).

In the Moselle area, Butzengeiger found signs of peripheral arterial disease in 41 cases among 180 vintners with chronic arsenic intoxication around 1939 (72). Of these cases, 20 reported coldness of the feet and hands and seven were diagnosed with 
acrodermatitis atrophicans Herxheimer, a rare cutaneous vascular disease with an inflammatory component. Six of the 15 that were clinically diagnosed with peripheral vascular disease showed gangrenous lesions, usually involving the hands and feet. A 33-year-old individual who suffered spontaneous amputation of the toes was also afflicted with gangrene of the glans penis. The median age of the 15 cases was 35 years, and only three cases were reported to have reduced pulsation of the dorsal arteries in the feet. Most cases were moderate or light smokers. The main exposure to arsenic was through "house drink" and wine. Butzengeiger (73) subsequently reported three more cases of gangrene of the extremities, four cases of lesser circulatory problems, and two cases with acrodermatitis atrophicans among 36 vintners with arsenic-induced electrocardiographic changes. Among 24 autopsies conducted between 1950 and 1956, thromboangiitis obliterans in skin and esophagus specimens were reported by Roth (74), who also described a vintner who suffered amputation of a leg at the age of 41 years.

A group of 100 surviving vintners were followed up between 1972 and 1975, 30 years after cessation of arsenic exposure (75). Acrocyanosis of arms and legs was reported to have occurred with high frequency (from 60 percent at age 50 years to 95 percent at age 95 years). Peripheral vascular disease was prevalent, leading to one amputation in a nonsmoker. It was mentioned that among the vintners not suffering from arsenic intoxication, only 1-2 percent suffered from vascular symptoms.

It was in the Moselle vintners that the relation between arsenic and angiosarcoma of the liver was first reported $(78,79)$. Angiosarcoma of the liver is very rare; until 1981 , there were fewer than 200 reports of it (80). Additional cases of angiosarcoma in association with arsenic have subsequently been described (81-88).

In Austria, 22 vintners with cutaneous signs of arsenicalism were described, one of whom suffered from gangrene of a finger (76).

\section{Assessment}

The clinical and pathologic vascular changes described above were sufficiently distinct from the atherosclerotic changes observed in the elderly, leading clinicians to strongly suspect that they were caused by arsenic. Although the reports are not formal epidemiologic studies and provide little information on selection of study subjects and disease occurrence among the nonexposed populations, case series are informative in rare disease situations (89). The severe peripheral vascular outcomes are rare in the young age groups involved. Furthermore, the lesions occurred among vintners with cutaneous signs of arsenicalism (70) and among vintners under clinical surveillance for chronic arsenic intoxication (72); gangrenous lesions were not reported among vintners prior to the use of arsenical pesticides.

We believe that the most likely explanation is a causal relation between arsenic and the peripheral vascular alterations.

\section{ARSENIC EXPOSURE VIA INHALATION}

Occupational studies of workers exposed to arsenic by inhalation have shown strong and consistent associations with lung cancer. The studies include several occupations in different countries, including sheep-dip manufacturing workers in Britain (90); smelter workers in Anaconda, Montana (91-94), Tacoma, Washington (95-97), Salt Lake City, Utah (98), Roennskar, Sweden (99-101), and Japan (102); patients with signs of arsenic poisoning working in or living around an ore mine with a refinery in Japan (103); and insecticide manufacturers in Michigan (104, 105) and Maryland (106). Most of these studies present results regarding mortality due to vascular diseases. Table 6 summarizes the risk ratio estimates for various groups of circulatory diseases from these investigations. The corresponding risk ratios for lung cancer are also shown for reference. 
TABLE 6. Occupational studies of arsenic inhalation with results for cardiovascular effects, and the corresponding lung cancer risk ratios

\begin{tabular}{|c|c|c|c|c|}
\hline $\begin{array}{c}\text { Study } \\
\text { (reference no.) }\end{array}$ & $\begin{array}{l}\text { Study } \\
\text { period }\end{array}$ & Cause of death & $\begin{array}{l}\text { Risk ratio } \\
\left(95 \% \mathrm{Cl}^{*}\right) \dagger\end{array}$ & $\begin{array}{l}\text { Lung cancer } \\
\text { risk ratio } \\
(95 \% \mathrm{Cl}) \dagger\end{array}$ \\
\hline \multicolumn{5}{|c|}{ Sheep dip manufacturing, Britain } \\
\hline $\begin{array}{l}\text { Hill and Faning } \\
(90)\end{array}$ & $1910-1943$ & Circulatory disease & $0.86(0.45-1.59) \ddagger$ & $4.47(1.55-11.27) \S$ \\
\hline \multicolumn{5}{|c|}{ Smelter, Anaconda, Montana } \\
\hline $\begin{array}{l}\text { Lee and Fraumeni } \\
\text { (91) }\end{array}$ & $1938-1963$ & $\begin{array}{l}\text { Heart disease }(400-443) \\
\text { Cerebrovascular disease } \\
(330-334)\end{array}$ & $\begin{array}{l}1.18(1.10-1.27) \\
1.10(0.93-1.29)\end{array}$ & $3.29(2.78-3.87)$ \\
\hline Lubin et al. (92) & $1964-1977$ & $\begin{array}{l}\text { Circulatory disease } \\
\quad(390-458) \eta \\
\text { Heart disease }(410-414) \uparrow \\
\text { Cerebrovascular disease } \\
\quad(430-438) \eta\end{array}$ & $\begin{array}{l}1.09(1.02-1.17) \\
1.08(0.99-1.17) \\
1.09(0.90-1.31)\end{array}$ & $1.66(1.39-1.96)$ \\
\hline Lee-Feldstein (94) & $1938-1977$ & $\begin{array}{l}\text { Heart disease (400-443)\# } \\
\text { Cerebrovascular disease } \\
\text { (330-334)\# }\end{array}$ & $\begin{array}{l}1.30(1.23-1.37) \\
1.24(1.10-1.40)\end{array}$ & $2.85(2.54-3.19)$ \\
\hline \multirow[t]{8}{*}{ Welch et al. (93) } & $1938-1978$ & $\begin{array}{l}\text { Ischemic heart disease } \\
(410-413) \pi\end{array}$ & & \\
\hline & & Heavy exposure & $1.77(1.32-2.31)$ & $5.22(3.34-7.76)$ \\
\hline & & Other exposure & $1.37(1.18-1.57)$ & $2.68(2.02-3.48)$ \\
\hline & & Among smokers & $1.47(1.26-1.70)$ & $3.19(2.43-4.11)$ \\
\hline & & $\begin{array}{c}\text { Among nonsmokers } \\
\text { Cerebrovascular disease } \\
(430-438) \eta\end{array}$ & $1.14(0.80-1.59)$ & $2.05(0.89-4.04)$ \\
\hline & & Heavy exposure & $0.87(0.32-1.89)$ & \\
\hline & & Other exposure & $1.48(1.12-1.93)$ & \\
\hline & & Smelter, Tacoma, Washing & & \\
\hline \multirow[t]{2}{*}{ Pinto et al. (95) } & $1946-1960$ & Cardiovascular disease & & \\
\hline & & All workers vs. state & $1.77(1.21-2.60)$ & \\
\hline \multirow{4}{*}{ Pinto et al. (96) } & $1949-1973$ & $\begin{array}{l}\text { Exposed vs. unexposed } \\
\text { Heart disease }(400-443) \#\end{array}$ & $\begin{array}{l}1.36(0.46-4.89) \ddagger \\
1.09(0.92-1.28)\end{array}$ & $3.05(2.08-4.30)$ \\
\hline & & $\begin{array}{l}\text { Coronary heart disease } \\
(420) \#\end{array}$ & $1.09(0.90-1.30)$ & \\
\hline & & All other heart disease & $1.09(0.70-1.62)$ & \\
\hline & & $\begin{array}{l}\text { Cerebrovascular disease } \\
\qquad(330-334) \#\end{array}$ & $1.13(0.82-1.52)$ & \\
\hline \multirow{3}{*}{$\begin{array}{l}\text { Enterline and } \\
\text { Marsh (97) }\end{array}$} & $1941-1976$ & Heart disease (440-443)\# & $0.93(0.84-1.02)$ & $1.95(1.59-2.37)$ \\
\hline & & $\begin{array}{l}\text { Cerebrovascular disease } \\
\qquad(330-334) \#\end{array}$ & $1.11(0.90-1.37)$ & \\
\hline & & Smelter, Salt Lake City, Ut & & \\
\hline \multirow[t]{2}{*}{ Rencher et al. (98) } & 1959-1969 & $\begin{array}{c}\text { Circulatory disease } \\
\qquad(390-458) \pi\end{array}$ & & \\
\hline & & Smelter vs. mine & $1.08 * *$ & $4.81 * *$ \\
\hline
\end{tabular}

TABLE 6. Continues

\section{Sheep-dip workers}

The study by Hill and Faning of workers exposed to arsenical sheep-dip powder pro- vided early evidence of elevated lung cancer risks (90). The age-unadjusted mortality odds ratio for all circulatory diseases was below unity, but about 40 percent of the 
TABLE 6. Continued

\begin{tabular}{|c|c|c|c|c|}
\hline $\begin{array}{c}\text { Study } \\
\text { (reference no.) }\end{array}$ & $\begin{array}{l}\text { Study } \\
\text { period }\end{array}$ & Cause of death & $\begin{array}{l}\text { Risk ratio } \\
\left(95 \% \mathrm{Cl}^{*}\right) \dagger\end{array}$ & $\begin{array}{l}\text { Lung cancer } \\
\text { risk ratio } \\
(95 \% \mathrm{Cl}) \dagger\end{array}$ \\
\hline \multicolumn{5}{|c|}{ Smelter, Roennskar, Sweden } \\
\hline \multirow[t]{2}{*}{ Axelson et al. (99) } & $1960-1976$ & $\begin{array}{l}\text { Circulatory disease } \\
\qquad(410-412,427-428)\end{array}$ & & \\
\hline & & Exposed vs. unexposed & $2.17(1.10-4.36) \mathrm{tt}$ & $5.03(2.21-11.44) \mathrm{t \dagger}$ \\
\hline \multirow[t]{2}{*}{ Jarup et al. (101) } & $\begin{array}{l}1928-1977 \\
1928-1981\end{array}$ & $\begin{array}{l}\text { Circulatory disease } \\
\text { Ischemic heart disease } \\
(410-413)\end{array}$ & $\begin{array}{l}1.32(1.20-1.44) \\
1.07(0.97-1.18)\end{array}$ & $\begin{array}{l}2.88(2.27-3.60) \\
3.72(3.05-4.50)\end{array}$ \\
\hline & & $\begin{array}{l}\text { Cerebrovascular disease } \\
(430-438) \eta\end{array}$ & $1.06(0.88-1.27)$ & \\
\hline \multirow[b]{2}{*}{$\begin{array}{l}\text { Tokudome and } \\
\text { Kuratsune (102) }\end{array}$} & & Smelter, Japan & & \\
\hline & $1949-1971$ & $\begin{array}{l}\text { Heart diseases }(393-398, \\
410-414,420-429) \uparrow \\
\text { Cerebrovascular disease } \\
(430-438) \Uparrow\end{array}$ & $\begin{array}{l}0.47(0.19-0.97) \\
0.76(0.50-1.11)\end{array}$ & $11.90(7.96-17.10)$ \\
\hline \multirow[t]{2}{*}{$\begin{array}{l}\text { Tsuda et al.ł¥ } \\
\text { (103) }\end{array}$} & $1973-1989$ & $\begin{array}{l}\text { Ischemic heart disease } \\
\qquad(410-414) \S \S\end{array}$ & $2.14(0.86-4.40)$ & $5.67(2.45-11.20)$ \\
\hline & & $\begin{array}{c}\text { Cerebrovascular disease } \\
(430-438) \S \S\end{array}$ & $0.77(0.33-1.52)$ & \\
\hline \multicolumn{5}{|c|}{ Insecticide manufacturing, Michigan } \\
\hline Ott et al. (104) & $1940-1973$ & Cardiovascular disease & $0.70(0.50-0.95)$ & $3.45(2.11-5.33)$ \\
\hline \multirow[t]{2}{*}{ Sobel et al. (105) } & $1940-1982$ & $\begin{array}{l}\text { Circulatory disease } \\
(390-458) \uparrow\end{array}$ & $0.80(0.65-0.98)$ & $2.25(1.56-3.12)$ \\
\hline & & Insecticide manufacturing, $\mathrm{Ma}$ & land & \\
\hline \multirow[t]{6}{*}{$\begin{array}{l}\text { Mabuchi et al. } \\
\quad(106)\end{array}$} & $1946-1977$ & $\begin{array}{c}\text { Circulatory disease } \\
(390-458) \Uparrow\end{array}$ & & \\
\hline & & Males & $0.84(0.67-1.04)$ & $1.61(1.03-2.40)\|\|$ \\
\hline & & Females & $1.19(0.74-1.82)$ & \\
\hline & & $\begin{array}{l}\text { Cerebrovascular disease } \\
\qquad(430-438) ף\end{array}$ & & \\
\hline & & Males & $0.99(0.45-1.88)$ & \\
\hline & & Females & $2.16(0.79-4.66)$ & \\
\hline
\end{tabular}

- Cl, confidence interval. 177).

f Mortality odds ratio, excluding cancer deaths.

$\S$ Mortality odds ratio, excluding other cancer and cardiovascular deaths.

I International Classification of Diseases, Sixth Revision, codes.

If International Classification of Diseases, Eighth Revision, codes.

\# International Classification of Diseases, Seventh Revision, codes.

* Comparative mortality figure, precision not estimable (but based on large numbers).

t† Odds ratio.

$\ddagger$ Mortality experience of 141 arsenic poisoning patients around a smelter (worker and nonworker). Arsenic inhaled and ingested.

$\S \S$ Intemational Classification of Diseases, Ninth Revision, codes.

II Both sexes.

workers within the factory were in fact unexposed (ref. 90, table 4).

\section{Smelter workers}

The studies of the smelter workers in Anaconda found elevated overall standardized mortality ratios for heart and cerebro- vascular diseases. However, no associations were found using surrogates for arsenic exposure like length of employment $(91,92)$, number of years at elevated exposure (92), and period of first employment (94). The analysis of a sample of 1,800 men from the original cohort of 8,047 found higher risks for ischemic heart diseases but 
not for cerebrovascular diseases among those with "heavy" exposure (93). For ischemic heart diseases, the standardized mortality ratio was higher in smokers, with increasing standardized mortality ratios associated with increasing peak but not with average arsenic exposure (ref. 93, table 12).

Workers in the Tacoma smelter showed increased risk of dying of cardiovascular diseases, especially at younger ages, in the earliest study by Pinto et al. (95). In a subsequent study (96) of 527 retirees, overall standardized mortality ratios were only slightly elevated, and no further analyses were presented. Enterline and Marsh (97) did not find an overall effect for heart and cerebrovascular disease in their study of 2,802 workers from the same cohort. Doseresponse analyses were reported only for respiratory cancer.

The circulatory mortality rates (19591969) were similar in smelter workers and reportedly unexposed miners in a study by Rencher et al. in Salt Lake City (98).

An early case-control study in Roennskar reported an odds ratio of 2.17 for circulatory disease related to arsenic exposure, with a statistically significant trend using four levels of exposure (99). A subsequent study found elevated standardized mortality ratios for ischemic heart disease, other heart diseases, and cerebrovascular diseases, resulting in an overall standardized mortality ratio for circulatory diseases of $1.32(100)$. A gradient for years of exposure and cerebrovascular diseases was observed. In contrast, Jarup et al. (101) found much smaller standardized mortality ratios for both ischemic heart diseases and cerebrovascular diseases, with no trends being observed by cumulative arsenic exposure. Physiologic studies of vasospastic tendency have also been conducted $(107,108)$. Increases in vasospastic reactivity, as well as history of Raynaud's phenomenon, were found in men who worked at the smelter compared with matched controls (107). It was concluded in a later study that these vascular effects of arsenic require long-term exposure (108).
A study in Japan found standardized mortality ratios for heart and cerebrovascular diseases which were below unity (102). However, an excess risk for ischemic heart disease mortality was found among 141 certified arsenic poisoning patients who worked in or lived around a Japanese ore mine (103). Arsenic exposure occurred by both inhalation and ingestion. Among 125 arsenic poisoning patients from the same area, 32 showed symptoms of Raynaud's disease and two suffered gangrene in the limbs (109).

\section{Insecticide production}

The studies of insecticide manufacturers (104-106) did not report increased cardiovascular disease risks, with the exception of an elevated but imprecise standardized mortality ratio for cerebrovascular diseases in females in one study (106).

\section{Case reports}

There are four case reports of vascular symptoms following arsenic inhalation (110-113) (table 7). Vascular manifestations ranged from symptoms of Raynaud's disease (110) to penile artery thrombosis in a 1-year-old infant (113). Exposure in the latter occurred through ingestion, dermal contact, and inhalation, and may have begun in utero.

\section{Assessment}

It is difficult to draw inferences based on these studies, since the results differ not only across studies but also within study populations. The pattern of increased lung cancer risk ratios accompanied by increased cardiovascular risk ratios is present in the Anaconda and Roennskar studies, but less so in the others. Most investigations focused mainly on respiratory cancer and did not attempt to analyze circulatory diseases in much detail. However, it is interesting that most relative risk estimates for the smelter workers for the main subgroups of circulatory diseases exceed unity, resulting in an overall standardized mortality ratio for heart diseases of 1.16 (95 percent 
TABLE 7. Case reports of vascular symptoms associated with arsenic inhalation and medication

\begin{tabular}{|c|c|c|c|c|}
\hline $\begin{array}{c}\text { Study } \\
\text { (reference no.) }\end{array}$ & $\begin{array}{c}\text { Age } \\
\text { (years) }\end{array}$ & Sex & Exposure & Symptoms \\
\hline \multicolumn{5}{|c|}{ Arsenic inhalation } \\
\hline Kraetzer (110) & 38 & Female & $\begin{array}{l}\text { Handling of arsenical } \\
\text { insecticides during } 14 \\
\text { years }\end{array}$ & $\begin{array}{l}\text { Painful Raynaud } \\
\text { symptomatology }\end{array}$ \\
\hline Oppenheim (111) & 54 & Male & $\begin{array}{l}\text { Wall paint containing } 3 \text { mg } \\
\text { arsenic per gram } \\
\text { (possibly arsine gas) }\end{array}$ & $\begin{array}{l}\text { Multiple gangrene of the skin } \\
\text { (tibia) }\end{array}$ \\
\hline Kren (112) & & & $\begin{array}{l}\text { Wall paint high in arsenic } \\
\text { (possibly arsine gas) }\end{array}$ & $\begin{array}{l}\text { Gangrene of toes and part of } \\
\text { calf }\end{array}$ \\
\hline \multirow[t]{2}{*}{ Peters et al. (113) } & 1 & Male & $\begin{array}{l}\text { Buming of chromium- } \\
\text { copper-arsenate con- } \\
\text { taining wood }\end{array}$ & Thrombosis of penile artery \\
\hline & 30 & Female & $\begin{array}{l}\text { Burning of chromium- } \\
\text { copper-arsenate } \\
\text { containing wood }\end{array}$ & Placenta previa or abruptio \\
\hline \multicolumn{5}{|c|}{ Arsenic in medicines } \\
\hline Cannon (115) & 38 & Female & $\begin{array}{l}\text { Fowler solution for chorea } \\
\text { at age } 12 \text { years }\end{array}$ & $\begin{array}{l}\text { Raynaud syndrome, } \\
\text { exacerbation by cold }\end{array}$ \\
\hline Knoth (116) & 42 & Male & $\begin{array}{l}\text { Ingestion of arsenic } \\
\text { solutions for psoriasis } \\
\text { for } 14 \text { years }\end{array}$ & $\begin{array}{l}\text { Amputation of leg due to } \\
\text { thromboangitis obliterans }\end{array}$ \\
\hline Strauss (117) & 34 & Male & $\begin{array}{l}\text { Inadvertent intramuscular } \\
\text { injection of } 50 \% \text { (instead } \\
\text { of } 0.5 \% \text { ) arsenic solution } \\
\text { at age } 20 \text { years }\end{array}$ & $\begin{array}{l}\text { Progressive gangrene with } \\
\text { amputation of both legs }\end{array}$ \\
\hline Dürck (118) & 30 & Male & $\begin{array}{l}\text { Injection of } 85 \text { times the } \\
\text { maximum level of an } \\
\text { arsenic solution }\end{array}$ & Loss of both legs \\
\hline
\end{tabular}

confidence interval (CI) 1.11-1.21) and for cerebrovascular disease of 1.13 (95 percent CI 1.03-1.23) (based on individual standardized mortality ratios derived from previously published studies $(94,97,101-$ 103)). In addition, when analyses were more detailed (e.g., taking into account smoking status (93)), associations began to appear that were previously undetected in the same group of workers $(91,92,94)$. The case reports add limited but supportive evidence of vascular disease associated with arsenic inhalation.

In summary, we cannot rule out the possibility of a modest relative risk increase for vascular disease in arsenic-exposed smelter workers. Although small relative risks combined with high background rates for vascular diseases may be difficult to detect, they may also indicate a significant public health problem.

\section{ARSENIC IN MEDICINES}

Among the studies investigating the health effects in patients treated with Fowler's solution (1 percent potassium arsenite), only one investigated vascular diseases. The mortality experience in a cohort of 478 patients who received Fowler's solution between 1945 and 1969 was reported (114). The standardized mortality ratios (SMR) were below unity for all circulatory diseases (SMR $=0.91,95$ percent CI 0.74 1.1), for ischemic heart disease (SMR = $0.85,95$ percent CI $0.6-1.1$ ), and for cerebrovascular diseases (SMR $=0.72,95$ percent $\mathrm{Cl}$ 0.4-1.1). The standardized mortality ratios for diseases of the arteries, arterioles, and capillaries are uninformative because of the small numbers (J. Cuzick, Imperial Cancer Research Fund, London, England, unpublished data, 1992). 
In a subcohort of 142 patients with cutaneous signs of arsenicalism, the standardized mortality ratio for all circulatory diseases was 1.04 (95 percent $\mathrm{CI} 0.6-1.7$ ), and it was 0.81 (95 percent $\mathrm{CI} 0.4-1.4$ ) in patients without such signs. The confidence intervals are wide, but standardized mortality ratios for all causes, and particularly for all neoplasms, were also higher in patients with signs of arsenicalism.

In addition to the cohort study just described, there are four case reports related to medicinal arsenic exposure (table 7). One woman had Raynaud's syndrome (115) and three young men suffered amputations of legs (116-118), unusual events for their ages. Fowler's solution $(115,116)$ and inadvertent injection of arsenic solutions $(117,118)$ accounted for the arsenic exposure.

\section{ANIMAL AND LABORATORY DATA}

The metabolism, distribution, and elimination of inorganic arsenic differ across species (119). Higher relative doses of arsenic are required to induce toxic effects in animals than in humans (120), and animal studies supply only limited evidence for carcinogenicity (121). In view of the species differences and the scientific focus on the carcinogenic effects of arsenic, it is not surprising that not much information can be derived from available in vitro and in vivo studies of the vascular effects.

The vascular effects of arsenic have been investigated only sporadically in cell culture $(122,123)$, in perfused hindlegs preparation of frogs (124) and rats (125), and in whole animals (126). One in vitro study suggested that human umbilical endothelial cells may be damaged by arsenite (122), and in another study, arsenite-induced damage of endothelial cells from bovine carotid arteries was reduced by pretreatment with glutathione, the protective effect of which may have been mediated by prostacyclin (123). The feeding of high doses of trivalent arsenic $(125,126)$ and artesian well water from the blackfoot disease area (124) led to an increase in vascular resistance.
Overall, the information derived from these studies is limited. There is no established animal model for the vascular effects of arsenic. Ideally, a good animal model would be analogous to the Watanabe heritable hyperlipidemic rabbits, which allowed the elucidation of cholesterol metabolism and whose pattern of atherosclerosis is indistinguishable from the human counterpart (127). Currently, therefore, the available evidence stems almost exclusively from epidemiologic data.

\section{DISCUSSION}

So far, the discussion of the evidence relating arsenic to vascular disease has remained within exposure source and exposed groups. Now, we will investigate the similarities and differences between the exposed populations, with particular interest in the differences between groups with respect to the presence or absence of gangrene and amputations.

\section{Severe peripheral vascular disease with gangrene and amputations: possible explanations of inconsistencies}

In the preceding sections, we have argued that a causal role for arsenic offers the best explanation for the occurrence of blackfoot disease in Taiwan and the occurrence of gangrene and amputations among the German vintners. The combined evidence from these two populations, together with other reports of gangrene or amputations $(42,47,48,50,54,69,109,111,112$, 116-118), provides good epidemiologic evidence for a causal role for arsenic. However, in terms of the frequency of gangrene and amputations, there are important differences between populations, with high occurrence in Taiwan and among German vintners, occasional reports from Latin America and Japan, and the absence of reports from smelter workers and a cohort of patients receiving Fowler's solution.

Arsenic dose. Bates et al. (ref. 2, table 5) have estimated and compared the cumulative total dose for the four types of arsenic-exposed populations described 
above. Moselle vintners, residents of the blackfoot disease area, high-exposure smelter workers, and Fowler's solution patients were estimated to have ingested or inhaled $17.5-175.2 \mathrm{~g}, 30 \mathrm{~g}, 6.8 \mathrm{~g}$, and $2.8 \mathrm{~g}$, respectively. The ingested total dose was far higher for German vintners and residents of the blackfoot disease area than for smelter workers and Fowler's solution patients. Populations in Chile, Mexico, and Argentina were exposed to levels of arsenic in drinking water comparable to those in the blackfoot disease endemic area in Taiwan.

While the arsenic dose may explain the absence of gangrene and amputations among the smelter workers and Fowler's solution patients, low occurrence of these conditions in several Latin American countries warrants the exploration of alternative explanations. If arsenic is a causative factor, then there must be other necessary factors (or absence of protective factors) that are more prevalent in the blackfoot disease area and among German vintners than in the Latin American populations. One such differentiating factor may be nutritional status.

Nutrition (zinc). Yang and Blackwell (24), suspecting the importance of dietary factors in the etiology of blackfoot disease, discussed the "miserable nature" of the residents' diet in the late 1950s, which consisted, in large part, of dried sweet potatoes. These authors hypothesized that the diet may have been lacking in essential fatty acids, and reported that the residents' intake of methionine was inadequate. Reference standards for amino acids have, however, been changed, and by today's standard the intake of sulfur-containing amino acids was adequate (2). The possibility of a marginal deficiency of essential fatty acids remains. Yang et al. (128) further tested the adequacy of the local diet by comparing the growth of rats raised on either the local diet or a control diet. The usual diet from the blackfoot disease area did not support adequate growth in rats, and this effect was independent of the presence of well water residue.
Epidemiologic evidence for a role of nutrition in blackfoot disease comes from the case-control study by Chen et al. (20), where high consumption of dehydrated potatoes and low consumption of eggs, meat, and vegetables were found to be risk factors. Engel and Receveur (129) have calculated the nutrient intake in this population based on the aggregated food consumption data presented by Yang and Blackwell (24). The results indicate that zinc intake may have been inadequate, with an average daily intake of 58 percent of the Recommended Dietary Allowance (130). The possibility of a role for marginal zinc intake in blackfoot disease is supported by reports of low zinc levels in whole blood, plasma, urine (131), and hair (132) in blackfoot disease patients compared with controls. In another study, blood zinc levels were also lower in blackfoot disease patients, but the difference was not statistically significant (133).

There are reasons to believe that German vintners may have had a marginal zinc status as well, because of mechanisms involving alcohol consumption and factors inhibiting zinc absorption. The alcohol consumption of the German vintners was very high. In addition to wine, daily consumption of several liters of "house drink" (2-5 percent alcohol) was common. Liver damage and cirrhosis occurred with high frequency (70). High urinary zinc excretion has been reported in alcoholics (134), but it is an open question whether hypozincemia and hyperzincuria, often observed in liver cirrhosis, are caused by the effect of ethanol on zinc metabolism or via liver damage (135). Arsenic itself can damage the liver (136).

The "house drink" may have contained substances that inhibit zinc absorption, such as copper $(137,138)$. The arsenical pesticides used by the vintners were often copper compounds (70). The house drink resulted from applying high pressure to aqueous infusion of the grape skins and the stems (77). This process may have resulted in the presence of appreciable amounts of lignin and hemicellulose. The high lignin 
content of the grape skin hinders its use in animal feed because it reduces digestibility (139), and the particular types of fibers present in grape skins (lignin and hemicellulose) have also been reported to inhibit zinc absorption in humans $(140,141)$.

We are not aware of a detailed nutritional assessment of the Latin American populations. Information concerning Argentina indicates that rich agriculture and cattle raising were characteristic of the region (65). The nutritional difference between the people of Argentina and Taiwan has been postulated as a possible explanation for the lack of blackfoot disease in Argentina, given that the diet there has a high protein content (62). However, it may be fitting that the affected children in Antofagasta, Chile, were of very low socioeconomic class and were reported to have nutritional deficiencies (48). The population in Mexico that was living in areas of arsenic-contaminated water had poor living and sanitary conditions (56).

\section{Biologic plausibility for a role of marginal zinc status}

At present, a detailed knowledge of the biologic bases for the vascular effects of chronic arsenic exposure is lacking, and the mechanisms by which arsenic causes cancer are not clearly understood. We nevertheless shall attempt to describe several possible mechanisms through which a marginal zinc status could play a role in the severe vascular manifestations of chronic arsenic exposure with its atherosclerotic and thrombotic manifestations $(22,49,74)$. These mechanisms may act independently or in concert, and include an imbalance of damage (arsenic) and repair (zinc), a protective effect of zinc on endothelial membranes and against actions of cytokines, decreased levels or activities of glutathione, glutathione $S$-transferase and superoxide dismutase, indirect competition of arsenic with zinc in proteins containing vicinal dithiols, and decreased intracellular availability of zinc through sequestration by arsenic-induced metallothionein. These mechanisms, with the exception of those acting on endothelial cells, may also be relevant to arsenic carcinogenicity. If so, then blackfoot disease patients would be at greater risk of developing arsenical cancer because of their increasing loss and requirement of zinc.

On a general level of explanation, there may be an ever-increasing imbalance between damage by arsenic and attempted repair requiring zinc during the course of the condition. In this sense, the gangrene itself, once started in patients with marginal zinc status, would increase zinc requirements for repair purposes (137), resulting in a self-perpetuating disease state.

Low zinc could make endothelial cells more vulnerable to arsenic, because zinc appears to be important in vascular endothelial barrier function $(142,143)$ and membrane integrity in general (144).

Cytokines display effects on endothelial cells (145), among which we consider tumor necrosis factor a candidate for mediating arsenic-induced gangrene, because tumor necrosis factor is involved in endotoxin-mediated intravascular coagulation and tissue necrosis (Shwartzman reaction). Zinc has been reported to inhibit tumor necrosis factor-induced disruption of endothelial cell integrity (142) and tumor necrosis factor-mediated DNA fragmentation and cytolysis of murine cells (146).

Glutathione levels inversely correlate with arsenic toxicity in a variety of systems $(123,147-150)$, including bovine endothelial cells (123). Glutathione is involved in arsenic methylation (151) and may stimulate prostacyclin (an inhibitor of platelet aggregation and smooth muscle cell proliferation) in arsenic-exposed endothelial cells (123). In zinc-deficient rats, blood glutathione levels were lower than in pairfed controls (152, 153). Following zinc treatment, glutathione levels increased in Chinese hamster ovary cells (154) and in rat hepatocytes (155). With respect to the protective effect of prostacyclin (123), it is interesting that the possibility was raised that zinc deficiency may decrease the number of prostacyclin receptors of the vasculature (156). 
Arsenic resistance in Chinese hamster ovary cells is associated with increased glutathione $S$-transferase activity $(149,157$, 158). In zinc-deficient rats, glutathione $S$ transferase activities were decreased (159, $160)$, and were restored following zinc replenishment (159). Zinc given subcutaneously increased glutathione $S$-transferase activity in mice (161), and glutathione $S$ transferase activity increased in Chinese hamster ovary cell lines following zinc treatment $(154,157)$.

Oxygen radicals may be involved in arsenite-induced damage, for the addition of the radical-scavenging enzyme superoxide dismutase decreased the frequency of arsenite-induced sister chromatid exchanges in human peripheral lymphocytes (162). In rat liver cells, the activity of superoxide dismutase increased upon incubation with physiologic zinc levels (155).

Finally, on a molecular level, arsenite may indirectly compete with zinc in metalbinding proteins displaying vicinal dithiols contained in zinc fingers of DNA binding and repair proteins and transcription factors $(163,164)$ and in protein kinase $C$ (which can be activated by tumor promoters such as phorbol esters) (165). Zinc finger in oncproteins have been proposed as targets for nickel, cobalt, and cadmium carcinogenicity $(163,166)$. Likewise, vicinal dithiols in zinc fingers have been proposed as targets for arsenite, implying the proteins' conformational change and altered biologic function $(167,168)$. Arsenite has been shown to bind in vitro to vicinal dithiols in the rat glucocorticoid receptor (169-171). While it is unlikely that arsenite can replace zinc ions from their position in already formed motifs, we speculate that arsenite may sometimes occupy the zinc binding site during protein synthesis or immediately following translation of the protein before zinc can be embedded into the site in a low zinc environment, especially when intracellular zinc availability may be further decreased by sequestration of zinc by metallothionein (172), which is inducible in vivo by arsenite (168) but is unknown to protect cells from arsenic (157).

\section{Mortality due to vascular diseases}

Mortality has been studied in the blackfoot disease area (17) and among workers exposed through inhalation. No clear inferences can be drawn from these studies. While there is indirect evidence that mortality rates due to diseases of the arteries, arterioles, and capillaries are higher in the blackfoot disease endemic area, the reported trends across arsenic categories for these diseases, as well as for cardiovascular diseases (17), could have been due to the mortality experience of blackfoot disease patients. While the results of smelter worker studies are interesting in that the pooled standardized mortality ratios for heart diseases and cerebrovascular diseases are above unity, they are not informative enough to allow for causal inference.

However, one can view gangrene and amputation as the tip of an iceberg, as a visible expression of a systemic disease. This view is supported by reports of high mortality due to vascular causes among blackfoot disease patients (20); of atherosclerotic changes of internal arteries and arterioles in blackfoot disease patients (3, 22), German vintners $(71,74)$, and children from Antofagasta (49); and of Raynaud's disease symptoms or acrocyanosis in smelter workers $(107,108)$, persons exposed to drinking water (45), persons living around a smelter (109), and German vintners (75).

\section{CONCLUSION}

There is good epidemiologic evidence that chronic arsenic consumption at high levels is a cause of severe peripheral vascular conditions with resulting gangrene and amputations of the limbs. We hypothesize that marginal zinc status may explain the differential occurrence of these severe conditions in populations ingesting large doses of arsenic. It is plausible, though there is limited epidemiologic evidence, that arsenic may cause increases in vascular mortality beyond that in patients with severe peripheral vascular disease. 
We believe that vascular effects should be included in the future study of the health effects of arsenic. The possible synergistic role of marginal zinc status in atherogenesis and carcinogenesis should be investigated, because zinc may constitute an easily administered preventive factor. Despite the known adverse health effects of arsenic, an estimated $112,000(173)$ to $347,000(174)$ persons in the United States are exposed to levels exceeding the maximum contaminant level of $50 \mu \mathrm{g} /$ liter in US water supplies (174), and other populations in Latin America, Taiwan, and Eastern Europe (175) are also exposed to high levels. The large number of people still exposed illustrates the potential public health benefit of a preventive factor.

\section{ACKNOWLEDGMENTS}

Support for this work was provided by grant 823B-026000 from the Swiss National Science Foundation, grants P42-ES04705 and P30ES01896 from the US National Institute for Environmental Health Sciences, and the health effects component of the University of California Toxic Substances Program.

The authors thank Dr. Toby Rossman for the helpful discussion regarding zinc, Mary Lou Biggs and Marcy Warner for helpful comments, and Renée Barroga for preparing the manuscript.

\section{REFERENCES}

1. Neubauer $\mathrm{O}$. Arsenical cancer: a review. $\mathrm{Br}$ Cancer 1947;1:192-251.

2. Bates MN, Smith AH, Hopenhayn-Rich C. Arsenic ingestion and internal cancers: a review. Am J Epidemiol 1992;135:462-76.

3. Ch'i IC, Blackwell RQ. A controlled retrospective study of blackfoot disease, an endemic peripheral gangrene disease in Taiwan. Am J Epidemiol 1968;88:7-24.

4. Tseng WP. Effects and dose-response relationships of skin cancer and blackfoot disease with arsenic. Environ Health Perspect 1977;19: 109-19.

5. Wu HY, Chen KP, Tseng WP, et al. Epidemiologic studies on blackfoot disease. I. Prevalence and incidence of the disease by age, sex, year, occupation and geographic distribution. Mem Coll Med Natl Taiwan U 1961;7:33-50.

6. Blackwell RQ. Speculations on the etiology of blackfoot disease. Taiwan I Hsueh Hui Tsa Chih 1961;60:460-72

7. Tseng WP, Chen WY, Sung JL. A clinical study of blackfoot disease in Taiwan, an endemic peripheral vascular disease. Mem Coll Med Natl Taiwan U 1961;7:1-17.

8. Chen KP, Wu HY, Wu TC. Epidemiologic studies on blackfoot disease in Taiwan. III. Physicochemical characteristics of drinking water in endemic blackfoot disease area. Mem Coll Med Natl Taiwan U 1962;8:115-29.

9. Chen KP, Wu HY. Epidemiologic studies on blackfoot disease. II. A study of source of drinking water in relation to the disease. Taiwan I Hsueh Hui Tsa Chih 1962;61:611-18.

10. Chen KP, Wu HY. Epidemiologic studies on blackfoot disease in Taiwan, China. IV. Relation of disease process with host and environmental factors. Taiwan I Hsueh Hui Tsa Chih 1965;64:456-69.

11. Wu HY, Chen KP. Epidemiologic studies on blackfoot disease in Taiwan, China. V. Statistical analysis of mortality and cause of death in the endemic area. Taiwan I Hsueh Hui Tsa Chih $1965 ; 64: 470-84$.

12. Chen KP, Wu HY. Epidemiologic studies on blackfoot disease in Taiwan, China. VI. Effect of the piped water supply on occurrence and disease progress of blackfoot disease. Taiwan I Hsueh Hui Tsa Chih 1969;68:291-6.

13. Tseng WP, Chu HM, How SW, et al. Prevalence of skin cancer in an endemic area of chronic arsenicism in Taiwan. J Natl Cancer Inst 1968;40:453-63.

14. Chen CJ, Chuang YC, Lin TM, et al. Malignant neoplasms among residents of a blackfoot disease endemic area in Taiwan: high-arsenic artesian well water and cancers. Cancer Res 1985;45:5895-9.

15. Chen CJ, Chuang YC, You SL, et al. A retrospective study on malignant neoplasms of bladder, lung and liver in blackfoot disease endemic area in Taiwan. Br J Cancer 1986;53:399-405.

16. Chiang HS, Hong CL, Guo HR, et al. Comparative study on the high prevalence of bladder cancer in the blackfoot disease endemic area in Taiwan. Taiwan I Hsueh Hui Tsa Chih 1988; 87:1074-80.

17. Wu MM, Kuo TL, Hwang YH, et al. Doseresponse relation between arsenic concentration in well water and mortality from cancers and vascular diseases. Am J Epidemiol 1989;130: 1123-32.

18. Chen CJ, Kuo TL, Wu MM. Arsenic and cancers. (Letter). Lancet 1988;1:414-15.

19. Chen CJ, Wang CJ. Ecological correlation between arsenic level in well water and age-adjusted mortality from malignant neoplasms. Cancer Res 1990;50:5470-4.

20. Chen CJ, Wu MM, Lee SS, et al. Atherogenicity and carcinogenicity of high-arsenic artesian well water: multiple risk factors and related malignant neoplasms of blackfoot disease. Arteriosclerosis 1988;8:452-60.

21. Tseng WP. Blackfoot disease in Taiwan: a 30 year follow-up study. Angiology 1989;40: 547-58.

22. Yeh S, How SW. A pathological study on the 
blackfoot disease in Taiwan. Rep Inst Pathol Natl Taiwan U 1963;14:25-73.

23. Yu HS, Sheu HM, Ko SS, et al. Studies on blackfoot disease and chronic arsenism in southern Taiwan, with special reference to skin lesions and fluorescent substances. J Dermatol 1984;11:361-70.

24. Yang TH, Blackwell RQ. Nutritional and environmental conditions in the blackfoot area. Formosa Sci 1961;15:101-29.

25. Criqui MH, Browner D, Fronek A, et al. Peripheral arterial disease in large vessels is epidemiologically distinct from small vessel disease: an analysis of risk factors. Am J Epidemiol 1989;129:1110-19.

26. International Agency for Research on Cancer, World Health Organization. Some metals and metallic compounds. (IARC Monographs on the Evaluation of the Carcinogenic Risk of Chemicals to Humans, vol 23). Lyon, France: International Agency for Research on Cancer, 1980.

27. Smith AH, Hopenhayn-Rich C, Bates MN, et al. Cancer risks from arsenic in drinking water. Environ Health Perspect 1992;97:259-67.

28. Risk Assessment Forum. Special report on ingested arsenic: skin cancer and nutritional essentiality. Washington, DC: Environmental Protection Agency, 1988. (EPA/625/3-87/ 013).

29. Mantel N. Chi-square tests with one degree of freedom: extensions of the Mantel-Haenszel procedure. J Am Stat Assoc 1963;58:690-700.

30. Lu FJ. Blackfoot disease: arsenic or humic acid? (Letter). Lancet 1990;336:115-16.

31. Lu FJ, Irgolic KJ, Lin CW, et al. Fluorescent compounds in drinking well water of black-foot disease endemic areas: ergotamine in the artesian well water. (In Chinese with English abstract). Taiwan I Hsueh Hui Tsa Chih 1982;81: 1087-100.

32. Lu FJ, Shih SR, Liu TM, et al. The effect of fluorescent humic substances existing in the well water of blackfoot disease endemic areas in Taiwan on prothrombin time and activated partial thromboplastin time in vitro. Thromb Res 1990;57:747-53.

33. Lu FJ. Arsenic as a promoter in the effect of humic substances on plasma prothrombin time in vitro. Thromb Res 1990;58:537-41.

34. Lu FJ, Lee YS. Humic acid: inhibitor of plasmin. Sci Total Environ 1992;114:135-9.

35. Lu FJ. Fluorescent humic substances and blackfoot disease in Taiwan. Appl Organometallic Chem 1990;4:191-5.

36. Davies DM. Textbook of adverse drug reactions. 4th ed. Oxford, England: Oxford University Press 1991:156.

37. Chen CJ. Blackfoot disease. (Letter). Lancet 1990;336:442

38. Lu FJ, Yang CK, Ling KH. Physico-chemical characteristics of drinking water in blackfoot endemic areas in Chia-I and Tainan Hsiens. (In Chinese with English abstract). Taiwan I Hsueh Hui Tsa Chih 1975;74:596-605.

39. Lu FJ, Liu TM. Fluorescent compounds in drinking water of blackfoot disease endemic areas: animal experimental model. (In Chinese with English abstract). Taiwan I Hsueh Hui Tsa Chih 1986;85:352-8.

40. Van Duuren BL, Melchionne S, Seidman I, et al. Chronic bioassays of chlorinated humic acids in B6C3F1 mice. Environ Health Perspect 1986;69:109-17.

$40 \mathrm{a}$. International classification of disease. Manual of the international statistical classification of diseases, injuries and causes of death-based on the recommendations of the eighth revision conference, 1965 , and adopted by the Nineteenth World Health Assembly. Geneva, Switzerland: World Health Organization, 1967.

41. Maclure M, Greenland S. Tests for trend and dose response: misinterpretations and alternatives. Am J Epidemiol 1992;135:96-104.

42. Geyer L. Über die chronischen Hautveränderungen beim Arsenicismus und Betrachtungen über die Massenerkrangungen in Reichenstein in Schlesien. (In German). Arch Dermatol Syphil Wien 1898;43:221-82.

43. Schwartz RA. Reichenstein disease. (Letter). Int J Dermatol 1991;30:304-5.

44. Holubar K. Reichensteiner Krankheit-Reichenstein disease. (Letter). Int J Dermatol 1991;30: 305.

45. Borgono JM, Vicent $\mathrm{P}$, Venturino $\mathrm{H}$, et al. Arsenic in the drinking water of the city of Antofagasta: epidemiological and clinical study before and after the installation of a treatment plant. Environ Health Perspect 1977;19:103-5.

46. Zaldivar R. Ecological investigations on arsenic dietary intake and endemic chronic poisoning in man: dose-response curve. Zentralbl Bakteriol [Orig B] 1977;164:481-4.

47. Zaldivar R. Arsenic contamination of drinking water and foodstuffs causing endemic chronic poisoning. Beitr Pathol 1974;151:384-400.

48. Zaldivar R, Guillier A. Environmental and clinical investigations on endemic chronic arsenic poisoning in infants and children. Zentralbl Bakteriol [Orig B] 1977;165:226-34.

49. Rosenberg HG. Systemic arterial disease and chronic arsenicism in infants. Arch Pathol 1974;97:360-5.

50. Moran S, Maturana G, Rosenberg $\mathrm{H}$, et al. Occlusion coronariennes liées a une intoxication arsenicale chronique. (In French). Arch Mal Coeur Vaiss 1977;70:1115-20.

51. Soto O, Romero $T$, Abadal J, et al. Infarto de miocardio: análisis de los 200 primeros casos atendidos en una Unidad Coronaria. (In Spanish). Rev Med Chil 1970;98:225-31.

52. Albores A, Cebrian ME, Tellez I, et al. Estudio comparativo de hidroarsenicismo crónico en dos comunidades rurales de la Región Lagunera de Mexico. (In Spanish). Bol Oficina Sanit Panam 1979;86:196-205.

53. Cebrian ME, Albores A, Aguilar $M$, et al. Chronic arsenic poisoning in the north of Mexico. Hum Toxicol 1983;2:121-33.

54. Cebrian ME. Some potential problems in assessing the effects of chronic arsenic exposure in north Mexico. (Preprint extended abstract). Presented at the meeting of the Division of Environmental Chemistry, American Chemical Society, New Orleans, Louisiana, 1987. 
55. Del Razo LM, Arellano MA, Cebrian ME. The oxidation states of arsenic in well-water from a chronic arsenicism area of northern Mexico. Environ Pollut 1990;64:143-53.

56. Cantellano Alvarado LC, Viniegra G, Garcia $\mathrm{RE}$, et al. El arsenicismo en la comarca lagunera: estudio epidemiológico de arsenicismo en las colonias Miguel Alemán y Eduardo Guerra, de Torreón, Coah. (In Spanish). Salud Publ Mex 1964;6:375-85.

57. Chavez A, Perez H, Tovar E, et al. Estudios en una comunidad con arsenicismo crónico endémico. II. Manifestaciones clínicas. (In Spanish). Salud Publ Mex 1964;6:432-5.

58. Tovar E, Chavez A, Hidalgo CP, et al. Estudios en una comunidad con arsenicismo crónico endémico. (In Spanish). Salud Publ Mex 1964;6: 443-9.

59. Ayerza A. Arsenicismo regional endémico. (In Spanish). Bol Acad Nac Med de Buenos Aires 1917;1:1-24.

60. Biagini RE. Hidroarsenicismo crónico en la República Argentina. (In Spanish). Med Cutan Ibero Lat Am 1975;6:423-32.

61. Besuschio SC, Perez Desanzo AC, Croci M. Epidemiological associations between arsenic and cancer in Argentina. Biol Trace Elem Res 1980;2:41-55.

62. Tello EE. Hydro-arsenicisms: What is the Argentina chronic hydro-arsenicism (HACRE)? Arch Argent Dermatol 1986;36:197-216.

63. Grinspan D, Biagini R. Hidroarsenicismo crónico regional endémico (HACRE): las manifestaciones de la intoxicación arsenical por el agua de consumo. (In Spanish). Med Cutan Ibero Lat Am 1985;13:85-109.

64. Biagini RE, Salvador M. Arsenicismo crónico en la provincia de Salta. (In Spanish). Arch Argent Dermatol 1983;33:193-7.

65. Bergoglio RM. Mortalidad por cancer en zonas de aguas arsenicales de la provincia de Córdoba, República Argentina. (In Spanish). Prensa Med Argent 1964;51:994-8.

66. Tello EE. Les epitheliomes d'origine arsenicale. (In French). Rev Fac Cien Med Univ Nac Cordoba 1962;20:197-206

67. Nicolli HB, O'Connor TE, Suriano JM, et al. Geoquímica del arsénico y de otros oligoelementos en aguas subterraneas de la llanura $\mathrm{Su}$ doriental de la provincia de Córdoba. (In Spanish). Cordoba, Argentina: Academia Nacional de Ciencias 1985; Miscelanea no 71.

68. Trelles RA, Largghi A, Paex JP. El problema sanitario de las aguas destinadas a la bebida humana, con contenido elevado de arsénico, vanadio y fluor. Fac Ingenieria Univ Bs As. (In Spanish). Instituto de Ingenieria Sanitaria 1970; 12:17-30

69. Torres Soruco CA, Biagini RE, Salvador MA Arteriopatía en pacientes con hidroarsenicismo crónico. (In Spanish). La Semana Med 1991; 175:35-8.

70. Koelsch F. Die beruflichen Arsenschäden im Weinbau und in den gewerblichen Betrieben. (In German). Arch Gewerbepath 1958;16: 405-38.

71. Hadjioloff $C$. Die Blutbildveränderungen bei der chronischen Arsenvergiftung der Winzer in der Rheinpfalz. (In German). Dtsch Med Wochenschr 1940;17:459-63.

72. Butzengeiger $\mathrm{KH}$. Über periphere Zirkulationsstörungen bei chronischer Arsenvergiftung. (In German). Klin Wochenschr 1940;22:523-7.

73. Butzengeiger KH. Über die chronische Arsenvergiftung. I. Ekg-Veränderungen und andere Erscheinungen am Herzen und Gefässsystem. II. Schleimhautsymptome und Pathogenese. (In German). Dtsch Arch klin Med 1948;194:1-16.

74. Roth F. Über die chronische Arsenvergiftung der Moselwinzer unter besonderer Berücksichtigung des Arsenkrebses. (In German). Ztschr Krebsforsch 1956;61:287-319.

75. Grobe JW. Periphere Durchblutungsstörungen und Akrocyanose bei arsengeschädigten Moselwinzern. (In German). Berufsdermatosen 1976; 24:78-84.

76. Kesztele V, Seyfried H. Chronische Arsenvergiftungen in den Weinbaugebieten der Ostmark. (In German). Arch Gewerbepath 1942; 11:361-8.

77. Straube G. Die chronische Arsen-Vergiftung der Winzer. (In German). Samml Vergiftungsfällen 1939;C45:33-8.

78. Roth F. Über die Spätfolgen des chronischen Arsenismus der Moselwinzer. (In German). Dtsch Med Wochenschr 1957;6:211-17.

79. Roth F. Arsen, Leber, Tumoren, Hämangioendotheliom. (In German). Ztschr Krebsforsch 1957;61:468-503.

80. Livaditou A, Alexiou G, Floros D, et al. Epithelioid angiosarcoma of the adrenal gland associated with chronic arsenical intoxication? Pathol Res Pract 1991;187:284-9.

81. Falk H, Caldwell GG, Ishak KG, et al. Arsenicrelated hepatic angiosarcoma. Am J Ind Med 1981;2:43-50.

82. Regelson W, Kim U, Ospina J, et al. Heman gioendothelial sarcoma of liver from chronic arsenic intoxication by Fowler's solution. Cancer 1968;21:514-22.

83. Lander JJ, Stanley RJ, Sumner HW, et al. Angiosarcoma of the liver associated with Fowler's solution (potassium arsenite). Gastroenterology 1975;68:1582-6

84. Roat JW, Wald A, Mendelow H, et al. Hepatic angiosarcoma associated with short-term arsenic ingestion. Am J Med 1982;73:933-6.

85. Kasper ML, Schoenfield L, Strom RL, et al Hepatic angiosarcoma and bronchioloalveolar carcinoma induced by Fowler's solution. JAMA 1984;252:3407-8.

86. Kadas I, Balazs L, Par A, et al. Angiosarkom der Leber nach kurzfristiger Arsenbehandlung. (In German). Zentralbl Allg Pathol 1985;130: 539-43.

87. Rennke H, Prat G, Etcheverry R, et al. Hemangioendothelioma maligno del higato $y$ arsenicismo cronico. (In Spanish). Rev Med Chil 1971;99:664-8.

88. Falk H, Herbert JT, Edmonds L, et al. Review of four cases of childhood hepatic angiosarcoma-elevated environmental arsenic exposure in one case. Cancer 1981:47:382-91.

89. Armenian HK. Case investigation in epidemiology. Am J Epidemiol 1992;134:1067-72.

90. Hill AB, Faning EL. Studies in the incidence of 
cancer in a factory handling inorganic compounds of arsenic. I. Mortality experience in the factory. Br J Ind Med 1948;5:1-15.

91. Lee AM, Fraumeni JF Jr. Arsenic and respiratory cancer in man: an occupational study. J Natl Cancer Inst 1969;42:1045-52.

92. Lubin JH, Pottern LM, Blot WJ, et al. Respiratory cancer among copper smelter workers: recent mortality statistics. J Occup Med 1981;23: 779-84.

93. Welch K, Higgins I, Oh M, et al. Arsenic exposure, smoking, and respiratory cancer in copper smelter workers. Arch Environ Health 1982;37:325-35.

94. Lee-Feldstein A. Arsenic and respiratory cancer in humans: follow-up of copper smelter employees in Montana. J Natl Cancer Inst 1983; 70:601-9.

95. Pinto SS, Bennett BM. Effect of arsenic trioxide exposure on mortality. Arch Environ Health 1963;7:583-91.

96. Pinto SS, Enterline PE, Henderson V, et al. Mortality experience in relation to a measured arsenic trioxide exposure. Environ Health Perspect 1977;19:127-30.

97. Enterline PE, Marsh GM. Cancer among workers exposed to arsenic and other substances in a copper smelter. Am J Epidemiol 1982;116: 895-911.

98. Rencher AC, Carter MW, McKee DW. A retrospective epidemiological study of mortality at a large western copper smelter. J Occup Med 1977;19:754-8.

99. Axelson O, Dahlgren $E$, Jansson $C D$, et al. Arsenic exposure and mortality: a case-referent study from a Swedish copper smelter. Br J Ind Med 1978;35:8-15.

100. Wall $S$. Survival and mortality pattern among Swedish smelter workers. Int J Epidemiol 1980; 9:73-87.

101. Jarup L, Pershagen G, Wall S. Cumulative arsenic exposure and lung cancer in smelter workers: a dose-response study. Am J Ind Med 1989;15:31-41.

102. Tokudome S, Kuratsune M. A cohort study on mortality from cancer and other causes among workers at a metal refinery. Int J Cancer 1976; 17:310-17.

103. Tsuda $T$, Nagira $T$, Yamamoto $M$, et al. An epidemiological study on cancer in certified arsenic poisoning patients in Toroku. Ind Health 1990;28:53-62.

104. Ott MG, Holder BB, Gordon HL. Respiratory cancer and occupational exposure to arsenicals. Arch Environ Health 1974;29:250-5.

105. Sobel W, Bond GG, Baldwin CL, et al. An update of respiratory cancer and occupational exposure to arsenicals. Am J Ind Med 1988;13: 263-70.

106. Mabuchi K, Lilienfeld AM, Snell LM. Cancer and occupational exposure to arsenic: a study of pesticide worker. Prev Med 1980;9:51-77.

107. Lagerkvist B, Linderholm H, Nordberg GF. Vasospastic tendency and Raynaud's phenomenon in smelter workers exposed to arsenic. Environ Res 1986;39:465-74.

108. Lagerkvist BE, Linderholm H, Nordberg GF. Arsenic and Raynaud's phenomenon: vasospas- tic tendency and excretion of arsenic in smelter workers before and after the summer vacation. Int Arch Occup Environ Health 1988;60: 361-4.

109. Hotta N. Clinical aspects of chronic arsenic poisoning due to environmental and occupational pollution in and around a small refining spot. Jpn J Constitutional Med 1989;53:49-70.

110. Kraetzer AF. Raynaud's disease associated with chronic arsenical retention-report of case cured by sodium thiosulfate. JAMA 1930;94: 1035-7.

111. Oppenheim $M$. Hauterkrankungen durch arsenhaltigen Mauerabstrich. (In German). Wien klin Wochenschr 1930;1:475-6.

112. Kren O. Discussion (of Oppenheim's paper, above). (In German). Wien klin Wochenschr 1930;1:476.

113. Peters HA, Croft WA, Woolson EA, et al. Seasonal arsenic exposure from burning chromium-copper-arsenate-treated wood. JAMA 1984;251:2393-6.

114. Cuzick J, Sasieni P, Evans S. Ingested arsenic, keratoses, and bladder cancer. Am J Epidemiol 1992:136:417-21.

115. Cannon AB. Chronic arsenical poisoningsymptoms and sources. N Y State J Med 1936; 36:219-41.

116. Knoth W. Arsenbehandlung. (In German). Arch klin Exp Dermatol 1966;227:228-34.

117. Strauss F. 56. Tagung der Deutschen Gesellschaft für Chirurgie. (In German). Arch klin Chir 1932;173:92-3.

118. Dürck H. Die pathologische Anatomie im Dienste der Unfallbegutachtung. III. (In German). München Med Wchnschr 1937;84:81-7.

119. Vahter M. Metabolism of arsenic. In: Fowler $\mathrm{BA}$, ed. Biological and environmental effects of arsenic. Amsterdam, The Netherlands: Elsevier Science Publishers, 1983:171-98.

120. Squibb KS, Fowler BA. The toxicity of arsenic and its compounds. In: Fowler, BA, ed. Biological and environmental effects of arsenic. Amsterdam, The Netherlands: Elsevier Science Publishers, 1983:233-69.

121. International Agency for Research on Cancer, World Health Organization. Overall evaluation of carcinogenicity: an updating of IARC monographs volumes 1 to 42 , supplement 7 . (IARC Monographs on the Evaluation of Carcinogenic Risks to Humans). Lyon, France: International Agency for Research on Cancer, 1987:100-6.

122. Chen GS, Asai T, Suzuki Y, et al. A possible pathogenesis for blackfoot disease-effects of trivalent arsenic (As2O3) on cultured human umbilical vein endothelial cells. J Dermatol 1990;17:599-608.

123. Chang WC, Chen SHC, Wu HL, et al. Cytoprotective effect of reduced glutathione in arsenical-induced endothelial cell injury. Toxicology 1991;69:101-10.

124. Chen WY, Yen TS. Experimental studies on the drinking water of blackfoot endemic area. (Part 2). Taiwan I Hsueh Hui Tsa Chih 1964;63: $150-8$.

125. Bekemeier H, Hirschelmann R. Reactivity of resistance blood vessels ex vivo after adminis- 
tration of toxic chemicals to laboratory animals: arteriolotoxicity. Toxicol Lett 1989;49:49-54.

126. Carmignani M, Boscolo $P$, Castellino N. Metabolic fate and cardiovascular effects of arsenic in rats and rabbits chronically exposed to trivalent and pentavalent arsenic. Arch Toxicol Suppl 1985;8:452-5.

127. Goldstein JL, Kita T, Brown MS. Defective lipoprotein receptors and atherosclerosis: lessons from an animal counterpart of familial hypercholesterolemia. N Engl J Med 1983;309: 288-96.

128. Yang TH, Blackwell RQ, Yu T, et al. Further animal growth studies of blackfoot dietary components. Taiwan I Hsueh Hui Tsa Chih 1961;60:1149-50.

129. Engel RR, Receveur O. Re: "Arsenic ingestion and internal cancers: a review." (Letter). Am J Epidemiol 1993;138:896-7.

130. National Research Council. Recommended dietary allowances. 10th ed. Washington, DC: National Academy Press, 1989.

131. Lin SM, Yang MH. Arsenic, selenium, and zinc in patients with blackfoot disease. Biol Trace Elem Res 1988;15:213-21.

132. Pan TC, Lin TH, Tseng CL, et al. Trace element in hair of blackfoot disease. Biol Trace Elem Res 1993;39:117-28.

133. Wang CT, Huang CW, Chou SS, et al. Studies on the concentration of arsenic, selenium, copper, zinc and iron in the blood of blackfoot disease patients in different clinical stages. Eur J Clin Chem Clin Biochem 1993;31: 759-63.

134. Sullivan JF, Lankford HG. Urinary excretion of zinc in alcoholism and post alcoholic cirrhosis. Am J Clin Nutr 1962;10:153-7.

135. Lieber CS. The influence of alcohol on nutritional status. Nutr Rev 1988;46:241-54.

136. Ishinishi $\mathbf{N}$, Tsuchiya $\mathrm{K}$, Vahter $\mathbf{M}$, et al. Arsenic. In: Friberg L, Nordberg GF, Vouk V eds. Handbook on the toxicology of metals. 2nd ed. Amsterdam, The Netherlands: Elsevier Science Publishers, 1986:43-83.

137. Underwood EJ. Trace elements in human and animal nutrition. 4th ed. New York, NY: Academic Press, Inc., 1977.

138. Castillo Duran C, Vial P, Uauy R. Oral copper supplementation: effect on copper and zinc balance during acute gastroenteritis in infants. Am J Clin Nutr 1990:51:1088-92.

139. Hankinson B. The histological, compositional, and textural properties of grape skins. Ph.D. thesis, University of Georgia, Athens, Georgia, 1977.

140. Kelsay JL, Jacob RA, Prather ES. Effect of fiber from fruits and vegetables on metabolic responses of human subjects. III. Zinc, copper, and phosphorus balances. Am J Clin Nutr 1979; 32:2307-11.

141. Kies C, Fox HM, Beshgetoor D. Effect of various levels of dietary hemicellulose on zinc nutritional status of men. Cereal Chem 1979; 56:133-6.

142. Hennig B, McClain CJ, Diana JN. Function of vitamin $\mathrm{E}$ and zinc in maintaining endothelial integrity: implications in atherosclerosis. Ann N Y Acad Sci 1993;686:99-109.
143. Hennig B, Wang Y, Ramasamy S, et al. Zinc deficiency alters barrier function of cultured porcine endothelial cells. J Nutr 1992;122: $1242-7$.

144. Liu J, Kershaw WC, Klaassen CD. Protective effects of zinc on cultured rat primary hepatocytes to metals with low affinity for metallothionein. J Toxicol Environ Health 1992;35: $51-62$.

145. Pober JS, Cotran RS. Cytokines and endothelial cell biology. Physiol Rev 1990;70:427-51.

146. Flieger D, Riethmüller $G$, Ziegler-Heitbrock HWL. $\mathrm{Zn}++$ inhibits both tumor necrosis factor-mediated DNA fragmentation and cytolysis. Int J Cancer 1989;44:315-19.

147. Hirata $M$, Hisanaga A, Tanaka A, et al. Glutathione and methylation of inorganic arsenic in hamsters. Appl Organometallic Chem 1988;2: 315-21.

148. Hirata M, Tanaka A, Hisanaga A, et al. Effects of glutathione depletion on the acute nephrotoxic potential of arsenite and on arsenic metabolism in hamsters. Toxicol Appl Pharmaco 1990;106:469-81

149. Lee TC, Wei ML, Chang WJ, et al. Elevation of glutathione levels and glutathione $S$-transferase activity in arsenic-resistant Chinese hamster ovary cells. In Vitro Cell Dev Biol 1989;25: 442-8.

150. Li W, Chou IN. Effects of sodium arsenite on the cytoskeleton and cellular glutathione levels in cultured cells. Toxicol Appl Pharmacol 1992;114:132-9.

151. Georis B, Cardenas A, Buchet JP, et al. Inorganic arsenic methylation by rat tissue slices. Toxicology 1990;63:73-84.

152. Mills BJ, Lindeman RD, Lang CA. Effect of zinc deficiency on blood glutathione levels. J Nutr 1981;111:1098-102.

153. Mills BJ, Lindeman RD, Lang CA. Differences in blood glutathione levels of tumor-implanted or zinc-deficient rats. J Nutr 1981;111: 1586-92.

154. Seagrave J, Tobey RA, Hildebrand CE. Zinc effects on glutathione metabolism relationship to zinc-induced protection from alkylating agents. Biochem Pharmacol 1983;32 3017-21.

155. Steinebach OM, Wolterbeek HT, Effects of zinc on rat hepatoma HTC cells and primary cultured rat hepatocytes. Toxicol Appl Pharmacol 1993;118:245-54.

156. Browning JD, Reeves PG, O'Dell BL. Zinc deficiency in rats reduces the vasodilation response to bradykinin and prostacyclin. J Nutr 1987;117:490-5

157. Lo JF, Wang HF, Tam MF, et al. Glutathione $S$-transferase $\pi$ in an arsenic-resistant Chinese hamster ovary cell line. Biochem J 1992;288 977-82.

158. Wang HF, Lee TC. Glutathione $S$-transferase $\pi$ facilitates the excretion of arsenic from arsenicresistant chinese hamster ovary cells. Biochem Biophys Res Commun 1993;192:1093-9.

159. Lee JSK, Fong LYY. Decreased glutathione transferase activities in zinc-deficient rats. Carcinogenesis 1986;7:1111-13.

160. Jagadeesan V. Study of activating and conju- 
gating enzymes of drug metabolism in zinc deficiency. Indian J Exp Biol 1989;27: 799-801

161. Cho CH, Fong LYY. The interaction of ethanol and zinc on hepatic glutathione and glutathione transferase activity in mice. Agents Actions 1990;29:382-5.

162. Nordenson I, Beckman L. Is the genotoxic effect of arsenic mediated by oxygen free radicals? Hum Hered 1991;41:71-3.

163. Sunderman FW Jr, Barber AM. Finger-loops, oncogenes, and metals. (Claude Passmore Brown Memorial Lecture). Ann Clin Lab Sci 1988; 18:267-88.

164. Berg J. Zinc finger domains: hypothesis and current knowledge. Annu Rev Biophys Chem 1990;19:405-21.

165. Ahmed S, Kozma R, Lee J, et al. The cysteinerich domain of human proteins, neuronal chimaerin, protein kinase $\mathrm{C}$ and diacylglycerol $\mathrm{ki}$ nase binds zinc; evidence for the involvement of a zinc-dependent structure in phorbol ester binding. Biochem J 1991;280:233-41.

166. Cherian MG, Huang PC, Klaassen CD, et al. National Cancer Institute workshop on the possible roles of metallothionein in carcinogenesis. Cancer Res 1993;53:922-5.

167. Engel R. Ecologic study of arsenic in drinking water and mortality in US counties. Ph.D. thesis, University of California at Berkeley, Berkeley, California, 1993.

168. Wang $Z$, Rossman TG. The carcinogenicity of arsenic. In: Chang LW, ed. Toxicology of metals. Boca Raton, FL: CRC Press (In press).

169. Simons SS Jr, Chakraborti PK, Cavanaugh AH. Arsenite and cadmium (II) as probes of glucocorticoid receptor structure and function. J Biol Chem 1990;265:1938-45.

170. Lopez S, Miyashita Y, Simons SS Jr. Structurally based, selective interaction of arsenite with steroid receptors. J Biol Chem 1990;265: $16039-42$.

171. Stancato LF, Hutchison KA, Chakraborti PK, et al. Differential effects of the reversible thiolreactive agents arsenite and methyl methanethiosulfonate on steroid binding by the glucocorticoid receptor. Biochemistry 1993;32: 3729-36.

172. Zeng J, Vallee BL, Kägi JHR. Zinc transfer from transcription factor IIIA fingers to thionein clusters. Proc Natl Acad Sci U S A 1991; 88:9984-8.

173. Marcus WL, Rispin AS. Treshold carcinogenicity using arsenic as an example. In: Cothern RC, Mehlman MA, Marcus W, eds. Risk assessment and risk management of industrial and environmental chemicals. (Advances in modern environmental toxicology, no. 15). Princeton, NJ: Princeton Publishing Company, 1988.

174. Science (Applications International Corporation). Estimated national occurrence and exposure to arsenic in public drinking water supplies, revised draft. Report prepared for the US Environmental Protection Agency, Washington, DC, 1987. (EPA contract no. 6801-7166).

175. Simons M. Bulgarians kept in dark on danger- ous pollution. San Francisco, CA: The San Francisco Chronicle, March 29, 1990.

176. Gardner MG, Altman DG, eds. Statistics with confidence. London, England: British Medical Journal, 1989.

177. Dean AD, Dean JA, Burton AH, et al. Epi info (version 5): a word processing, database and statistics program for epidemiology on microcomputers. Stone Mountain, GA: USD, Inc., 1990.

\section{APPENDIX}

\section{Trends in mortality within the blackfoot disease endemic area may be due to blackfoot disease patients}

In the paper by Wu et al. (17), 27 of the 42 villages included in the study were in the four townships of Peimen, Hsuechia, Putai, and Ichu, and 15 villages were in the two townships of Yensui and Hsiaying, all in Taiwan. In the latter two townships, most villages were in the lowest arsenic category (ref. 17, figure 1), and according to the map in the paper by $\mathrm{Ch}^{\prime} \mathrm{i}$ and Blackwell (ref. 3, figure 3), only four cases occurred there by 1963 . This pattern of villages falling into the low arsenic category coinciding with low occurrence of blackfoot disease is repeated for the northern villages in Ichu and the eastern villages of Hsuechia. Most blackfoot disease patients resided, therefore, in villages in the middle and high arsenic categories. A trend might have been created by blackfoot disease patients who died of the particular cause in the two higher categories. The number of blackfoot disease patients and their causes of death $(20$, 21) are such that they may account for excess rates in the middle and higher arsenic categories. Gangrene accounted for 12.4 percent of deaths and heart diseases for 19.8 percent of deaths in 864 deceased blackfoot disease patients (21) between 1958 and 1982. Under the assumption that 36 patients die each year, one would expect 468 deaths during the period 1973-1986, resulting in 58 (12 percent) dying of gangrene and 93 (19.8 percent) of heart diseases. Based on the visual inspection of the two maps (ref. 17, figure 1, and ref. 3, figure 3) and the person-years of observation in the middle and higher arsenic categories (ref. 17, table 1), we estimate that half of the mortality of blackfoot disease patients was included. If so, the mortality experience of blackfoot disease patients may account for the observed trends, since 30 of the 80 deaths due to diseases of the arteries, arterioles, and capillaries and 45 of 277 deaths due to cardiovascular disease could be attributed to deceased blackfoot disease patients. 